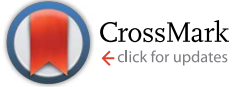

Cite this: RSC Adv., 2017, 7, 17968

\title{
Synthesis of methylated quercetin analogues for enhancement of radical-scavenging activity $\dagger$
}

\begin{abstract}
Kohei Imai, ${ }^{* a b}$ Ikuo Nakanishi, ${ }^{* b}$ Kei Ohkubo, ${ }^{\text {bc }}$ Yusuke Ohba, ${ }^{a}$ Takuya Arai, ${ }^{a}$ Mirei Mizuno, ${ }^{a}$ Shunichi Fukuzumi, ${ }^{\text {de }}$ Ken-ichiro Matsumoto ${ }^{b}$ and Kiyoshi Fukuhara ${ }^{a}$

Three quercetin derivatives with enhanced radical-scavenging activity were designed and synthesised. Because the radical-scavenging reaction of quercetin is known to proceed via an electron transfer from quercetin to radicals, producing the corresponding quercetin radical cation intermediate, the introduction of electron-donating groups into the quercetin molecule is expected to enhance its radicalscavenging activity. Thus, methyl groups were introduced into the catechol moiety in the quercetin molecule at either the $2^{\prime}$ - or $5^{\prime}$-position, or both. All three quercetin analogues were found to exhibit higher radical-scavenging activity than the parent quercetin. The activity of $5^{\prime}$-methylquercetin is the highest among the three analogues. The optimised structure of $5^{\prime}$-methylquercetin calculated by density functional theory demonstrated a coplanar structure between the $4 \mathrm{H}$-curomen (AC rings) and catechol (B ring) moieties, while dimethylquercetin and $2^{\prime}$-methylquercetin have a twisted structure between the $A C$ and $B$ rings. These results demonstrate that the highest radical-scavenging activity of $5^{\prime}$ methylquercetin is due to the stabilisation of the radical cation intermediate by the electron-donating effect of the methyl group as well as by the planar structure of the molecule.
\end{abstract}

Received 24th February 2017 Accepted 9th March 2017

DOI: $10.1039 / \mathrm{c} 7 \mathrm{ra02329d}$

rsc.li/rsc-advances of hydrogen-transfer reactions of phenolic antioxidants, namely a one-step hydrogen-atom transfer (route A), or electron transfer followed by proton transfer (route B), as shown in Fig. 1. ${ }^{\mathbf{1 2 - 1 4}}$ Resveratrol $^{15}$ and flavonoids, such as catechin ${ }^{16,17}$ and quercetin, ${ }^{18}$ are known to scavenge radicals via the electron transfer mechanism. In this case, solvents significantly affect the radical-scavenging mechanism. ${ }^{19}$ In fact, the radical-scavenging reaction of a vitamin $\mathrm{E}$ analogue proceeds via the one-step hydrogen-atom transfer in aprotic media, such as acetonitrile, ${ }^{20}$ while the electron-transfer process is involved in protic solvents, such as methanol. ${ }^{21}$ In this study, we focused on quercetin (2-(3,4-dihydroxyphenyl)-3,5,7-trihydroxy$4 H$-chromen-4-one), as a potential therapeutic agent to prevent illnesses caused by reactive oxygen radicals. Quercetin, which is the most common antioxidant found in citrus fruit and onions,

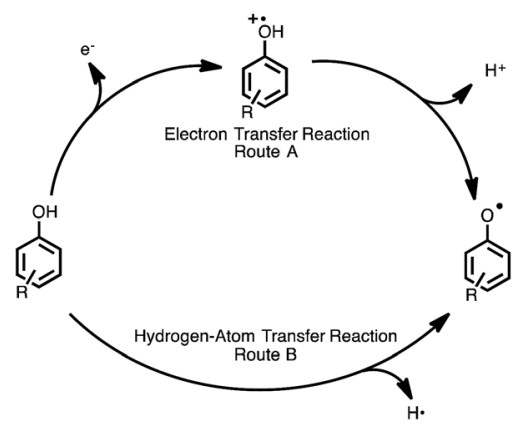

Fig. 1 Radical-scavenging mechanism of phenolic antioxidants. 
exhibits not only the ability to scavenge radicals, but also antiinflammatory and anticancer effects. ${ }^{22}$ Wai Mun Loke et al. also reported that quercetin may attenuate atherosclerosis in vivo. ${ }^{23}$ Furthermore, quercetin has been shown to inhibit the proliferation of breast cancer, human lung cancer and nasopharyngeal carcinoma cells. ${ }^{\mathbf{1 , 1 4 , 2 4 - 2 6}}$

Increased importance of considering antioxidative capabilities in drug development has led to an interest in improving the radical-scavenging activity of quercetin. Furthermore, the chemical modification of natural antioxidants provides valuable fundamental information about the structure-radical scavenging activity relationship of compounds.

Our efforts in derivatising quercetin to enhance its radicalscavenging activity were inspired by the methoxy group in the ferulic acid (caffeic acid structure), due to its proven antioxidative effects. ${ }^{27}$ The electron-donating group such as methoxy group at the ortho position relative to the hydroxy group stabilises radical cation. In the electron-transfer mechanism, the ionisation potential (IP) of the compound is important for its radical-scavenging efficacy. Introduction of an electron-donating group, such as methyl group, at positions ortho and/or para to the phenolic hydroxy group would decrease the IP of the phenolic compound, and thereby enhance the radical-scavenging activity.

Recently, we reported that resveratrol derivatives, in which methyl groups were introduced at the position ortho to the hydroxy group, showed enhanced radical-scavenging activities. The radical-scavenging activities of resveratrol derivatives 4 and 5 were shown to be about 14- and 36-fold higher than that of the parent resveratrol (Fig. 2). ${ }^{28}$ Similarly, introduction of methyl groups into the catechol moiety of catechin resulted in an enhanced radical-scavenging activity relative to the underivatised catechin. Specifically, the radical-scavenging activity of the dimethylcatechin derivative 6 (Fig. 2) was shown to be about 28 -fold higher than that of (+)-catechin. ${ }^{29}$ In addition to a methyl group, an isopropyl fragment was also introduced as

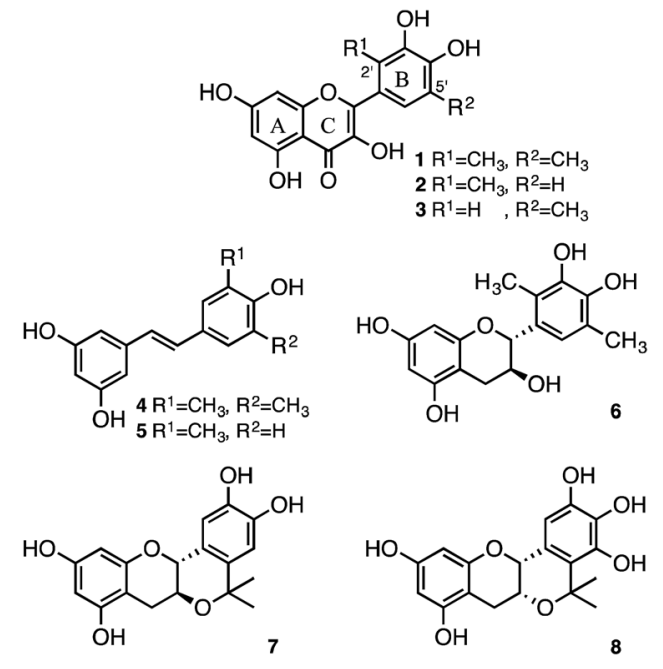

Fig. 2 Chemical structures of synthetic antioxidants. an electron-donating group to enhance the radical-scavenging activity. A planar-catechin analogue 7 (Fig. 2), in which an isopropyl fragment was introduced into (+)-catechin, exhibited 5fold more potent radical-scavenging activity compared to (+)-catechin. ${ }^{30}$ The conformationally constrained epigallocatechin analogue containing an isopropyl fragment 8 (Fig. 2) showed 16-fold more potent radical-scavenging activity than the parent epigallocatechin. ${ }^{31}$ We report herein the design and synthesis of $2^{\prime}, 5^{\prime}$-dimethylquercetin (1), $2^{\prime}$-methylquercetin (2), and $5^{\prime}$-methylquercetin (3) for enhancement of the radicalscavenging activity relative to the underivatised quercetin. The radical-scavenging activity of the quercetin analogues is expected to be enhanced upon introduction of a methyl group at positions ortho to the catechol hydroxy group, similar to the dimethylcatechin analogue 6. It should be noted that while it is very difficult to control the stereochemistry during the synthesis of the dimethylcatechin analogue $\mathbf{6}$, the synthesis of quercetin analogues was expected to be easier, because there is no need to control the stereochemistry. Herein, we also demonstrate their enhanced radical-scavenging ability against galvinoxyl radical $\left(\mathrm{GO}^{\circ}\right)$ as a reactivity model of reactive oxygen species.

\section{Results and discussion}

\section{Design and synthesis of quercetin analogues}

Quercetin analogues (1, 2, and 3) were synthesised in which methyl groups were introduced at the positions ortho to the hydroxy groups of the catechol moiety to enhance the radicalscavenging activity. These analogues were designed with reference to the dimethylcatechin analogue 6. Similar to catechin, quercetin scavenges free radicals via an electron-transfer reaction. ${ }^{18}$ Radical cations formed after the electron-transfer reaction are delocalised and stabilised by the introduction of an electron-donating group. Moreover, the radical cation intermediate of quercetin was expected to be even further stabilised by the effect of both electron donation and hyperconjugation of the methyl group.

The retrosynthesis of quercetin analogues $\mathbf{1 , 2}$ and $\mathbf{3}$ is shown in Scheme 1. The flavone scaffold can be synthesised via the Algar-Flynn-Oyamada (AFO) reaction from the chalcone structure, which is a useful way to form the flavone scaffold. ${ }^{32-34}$ The chalcone structure can be synthesised by Aldol condensation using an aldehyde and an acetophenone. The acetophenone forms the A ring of the quercetin molecule, while the aldehyde forms the $\mathrm{B}$ ring. The target molecules $(\mathbf{1}, \mathbf{2}$ and $\mathbf{3})$ contain methyl groups in the B ring, which are introduced into the starting aldehyde. Previously, the aldehyde derivative 9a, in which methyl groups were introduced at both positions ortho to the catechol hydroxy groups, had been synthesised to obtain the dimethyl catechin analogue 6. The intermediate (11) of 9a had been obtained by catalytic reduction after introduction of morpholine structure to catechol with Mannich reaction. ${ }^{29}$ Because the catalytic reduction is a dangerous reaction that is carried out at $70{ }^{\circ} \mathrm{C}$ and $5 \mathrm{~atm}$, another route was employed for the synthesis of $\mathbf{9 a}$.

Synthesis of the aldehyde derivative 9a used in this study is shown in Scheme 2. Dimethyl catechol 11 was obtained by the 
<smiles></smiles><smiles>C=CC=C</smiles><smiles>[R2]c1cc(/C=C/C(=O)c2c(O)cc(OCc3ccccc3)cc2O)c([R])c(OCc2ccccc2)c1OCc1ccccc1</smiles><smiles>[R]c1cc(C=O)c([R])c(OCCCCC)c1OCC(=O)Oc1cc(OCc2ccccc2)cc(O)c1C(C)=O</smiles>

9a: $\mathrm{R}^{1}=\mathrm{CH}_{3}, \mathrm{R}^{2}=\mathrm{CH}_{3}$ 9b: $\mathrm{R}^{1}=\mathrm{CH}_{3}, \mathrm{R}^{2}=\mathrm{H}$

9c: $R^{1}=\mathrm{H}, \quad \mathrm{R}^{2}=\mathrm{CH}_{3}$

Scheme 1 Retrosynthesis of methyl quercetin analogues.

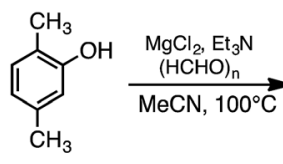<smiles>Cc1ccc(C)c(C=O)c1O</smiles>

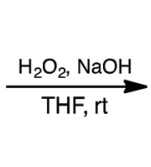<smiles>Cc1ccc(C)c(O)c1O</smiles><smiles>Cc1cc(C=O)c(C)c(O)c1O</smiles><smiles>CCCCCc1c(C)cc(C=COC(=O)C(C)(C)C)c(C)c1OCc1ccccc1</smiles>

Scheme 2 Synthesis of dimethyl aldehyde derivative 9a

Dakin reaction after formylation of 2,5-dimethylphenol..$^{35}$ Following formylation of $\mathbf{1 1}$ at the 4-position, protection of the hydroxy groups of $\mathbf{1 3}$ with benzyl bromide was accomplished to yield 9a. The AFO reaction, after Aldol condensation of 9a and 10a, is shown in Scheme 3. Acetophenone derivative (10a) was obtained by benzylation of the hydroxy groups at the 2- and 4positions of 2,4,6-trihydroxyacetophenone. The chalcone 14 was obtained by the aldol condensation of 9a with 10a. We initially attempted formation of flavone structure by the AFO reaction; however, the flavone structure was not formed. Instead, the aurone structure (16) was formed, followed by hydrogenation to yield 17.

We had deluded ourselves into taking that 15 was obtained by the AFO reaction because the ${ }^{1} \mathrm{H}$-NMR spectra of $\mathbf{1 5}$ and 16 were similar. Therefore, the catalytic reduction to give $\mathbf{1}$ was carried out, however, the compound 17 instead of 1 was obtained.
When the catalytic reduction was performed, the resulting yellow reaction solution turned colorless. This reduction reaction was performed not only for deprotection, but also for reduction of the unsaturated aurone bond. If, instead, the quercetin structure (15) had been synthesised by the AFO reaction, only the deprotection reaction of the benzyl group would have occurred following catalytic hydrogen reduction, and the color of reaction solution should have remained yellow. However, the reaction solution became colorless upon catalytic hydrogen reduction. Thus, the AFO reaction of $\mathbf{1 4}$ yielded the aurone structure (16) without the quercetin structure (15).

Epoxide may be predicted to be formed as an intermediate when the chalcone structure contains a substituent at the 6position, as in 14. The AFO reaction of chalcone with a substituent at the 6-position has previously been reported by various authors. Formation of the epoxide intermediate takes place by attack of the 2-O group at the $\alpha$-rather than at the $\beta$-position. ${ }^{36,37}$ Therefore, the AFO reaction of $\mathbf{1 4}$ yielded the aurone structure (16) (Scheme 4).

We attempted to introduce a hydroxy group to $\mathbf{1 8}$ at the 3position with dimethyldioxirane (DMDO) to yield 15. The chalcone structure (14) was reacted with $\mathrm{I}_{2}$ in DMSO to yield 18. While the cyclisation reaction was successful, hydroxylation of 18 with DMDO failed to yield 15.

Following these initial attempts, quercetin analogues were subsequently synthesised with other scheme which is via the taxifolin framework (22a) intermediate, as shown in Scheme 5. The synthetic scheme was employed with reference to the<smiles>CC(=O)c1c(O)cc(O)cc1Oc1ccccc1</smiles>

Scheme 3 Formation of dimethyl aurone structure 17. 


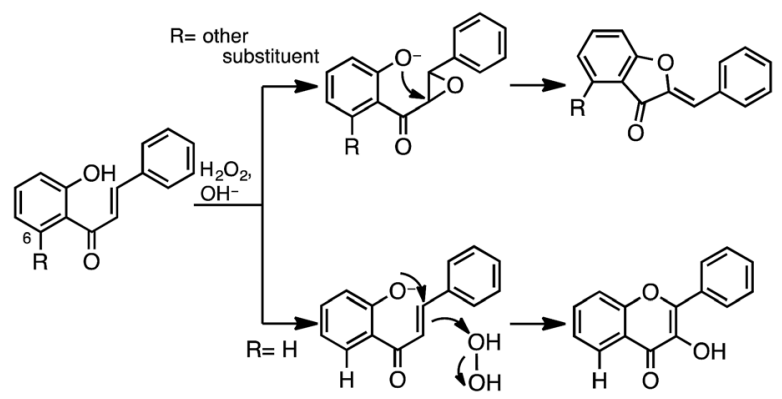

Scheme 4 AFO reaction.

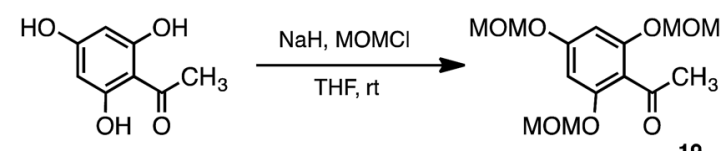

Scheme 5 Synthesis of 19.

synthesis of isorhamnetin, tamarixetin, and kaempferide. The protective group of acetophenone derivative (19) was changed from a benzyl group to methoxymethyl (MOM). The protection of all the hydroxy groups of acetophenone allows for termination of the reaction of epoxide conversion to aurone. The MOM was employed to be easily deprotected after formation of epoxide. The taxifolin framework (22a) should be obtained by the deprotection of MOM and cyclisation in a 1-pot reaction with 21a. The 2,4,6-tri-MOM phloracetophenone (19) was first synthesised, in which three hydroxy groups were protected by MOM groups (Scheme 5). ${ }^{38-40}$ The chalcone derivative 20a was subsequently obtained by condensation of 19 with the aldehyde derivative 9a. Next, epoxidation of 20a with hydrogen peroxide in the presence of sodium hydroxide as a base yielded 21a. ${ }^{41}$ Cyclisation of 21a was achieved at the same time as deprotection of MOM with hydrochloric acid. Catalytic hydrogenation of 22a with $20 \% \mathrm{Pd}(\mathrm{OH})_{2}$ yielded 23a. Finally, oxidation of 23a with potassium metabisulfite solution was performed to yield dimethyl quercetin (1) (Scheme 6). ${ }^{42}$

The aldehyde derivatives $\mathbf{9 b}$ and $\mathbf{9 c}$ were synthesised to obtain the quercetin analogues 2 and $\mathbf{3}$, respectively (Scheme 7).

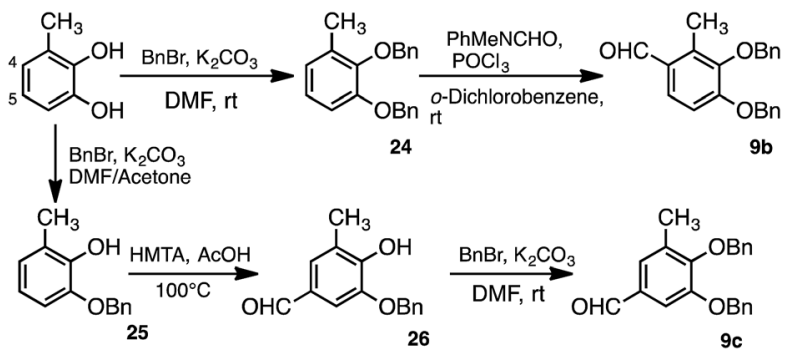

Scheme 7 Synthesis of monomethyl aldehyde derivative $9 b$ and 9c.

Formylation of 24, which was benzylated using 3-methylcatechol, at the 4-position was carried out by the VilsmeierHaack reaction to yield $\mathbf{9 b}$. The aldehyde derivative $\mathbf{9 c}$ was also synthesised from 3-methylcatechol. Specifically, 3-methylcatechol was first benzylated at the 1-position of the hydroxy group to yield 25. Formylation of $\mathbf{2 5}$ at the $\mathbf{5}$-position was then achieved via the Duff reaction using hexamethylenetetramine (HMTA). ${ }^{43,44}$ The aldehyde derivative $9 \mathrm{c}$ was then obtained by benzylation at the 2-position of the hydroxy group. Quercetin analogues 2 and 3 were synthesised with the resulting $\mathbf{9 b}$ and 9c, respectively, by the same scheme used to obtain dimethylquercetin (1) (Scheme 6).

\section{Radical-scavenging activity of quercetin analogues monitored by the stopped flow technique}

The radical-scavenging activity of quercetin analogues was evaluated in a non-aqueous system using the galvinoxyl radical $\left(\mathrm{GO}^{\circ}\right)$ as a reactivity model of reactive oxygen species. $\mathrm{GO}^{\circ}$ exhibits a strong absorption band at $428 \mathrm{~nm}$, and a solution of $\mathrm{GO}^{*}$ appears yellow in color. ${ }^{21,45}$ Upon mixing of $\mathrm{GO}^{*}$ with an antioxidant, the visible absorption band immediately vanishes, and the resulting decolorization is stoichiometric with respect to the number of electrons taken up. The rates of $\mathrm{GO}^{\circ}$-scavenging by the quercetin analogues were measured based on the color change of $\mathrm{GO}^{\circ}$ in the presence of antioxidants. Because this spectral change occurs very fast, the rates of the radicalscavenging reaction of quercetin analogues were measured by monitoring the decrease in absorbance at $428 \mathrm{~nm}$ using a stopped flow technique in deaerated acetonitrile at $298 \mathrm{~K}$. The

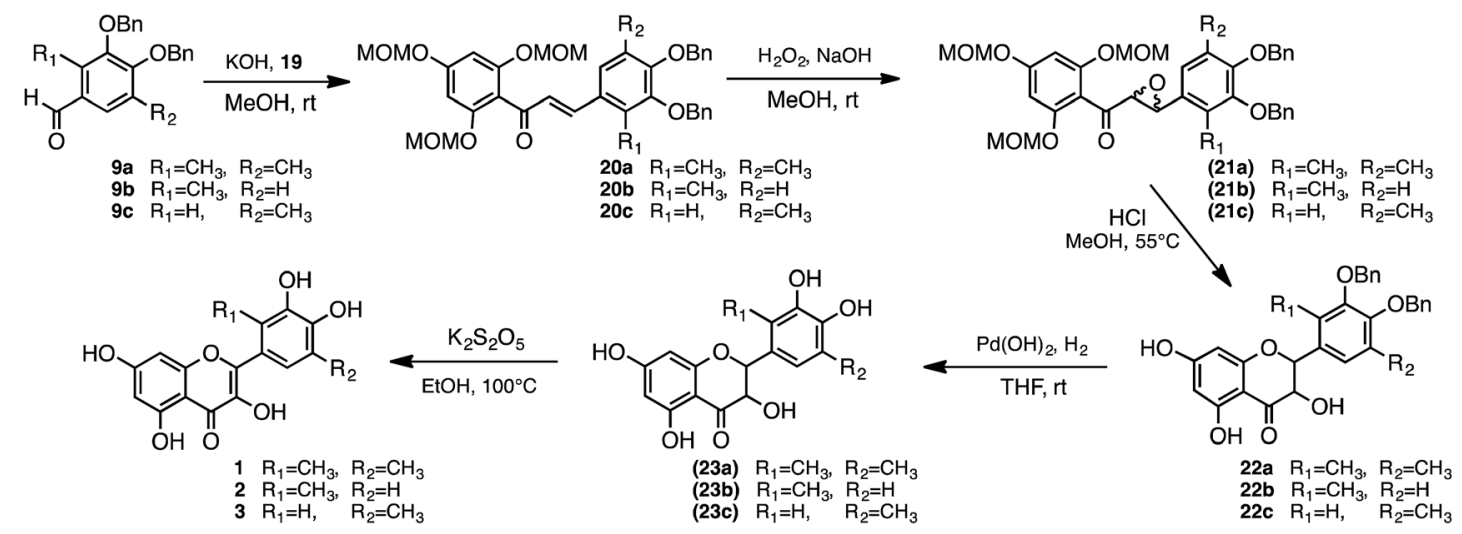

Scheme 6 Formation of quercetin analogues 1, 2 and 3. 
decay of the absorbance at $428 \mathrm{~nm}$ obeyed pseudo-first-order kinetics when the concentration of 2 ([2]) was maintained at more than 10 -fold excess to the $\mathrm{GO}^{*}$ concentration. The decay of the absorbance at $428 \mathrm{~nm}$ of $\mathrm{GO}^{\circ}$ is shown in Fig. 3. The pseudofirst-order rate constant $\left(k_{\text {obs }}\right)$ increased linearly with an increase in the concentration of quercetin analogues. An extended figure for 1, 2 and quercetin is included as an insert in Fig. 4 because the $k$ value of 3 is too large; the insert shows a magnified axis for $k_{\mathrm{obs}}$ from 0 to $2 \mathrm{~s}^{-1}$. From the slope of a linear plot of $k_{\text {obs }} v s$. [2], the second-order rate constant $(k)$ for the radical-scavenging reaction was determined to be $6.1 \times 10$ $\mathbf{M}^{-1} \mathrm{~s}^{-1}$. The $k$ values for dimethylquercetin (1), $5^{\prime}$-methylquercetin (3), and the parent quercetin were determined in the same manner to be $2.1 \times 10^{3} \mathrm{M}^{-1} \mathrm{~s}^{-1}, 1.6 \times 10^{5} \mathrm{M}^{-1} \mathrm{~s}^{-1}$, and $1.1 \times 10 \mathrm{M}^{-1} \mathrm{~s}^{-1}$, respectively (Fig. 4). These results demonstrate that the $k$ values for 1,2 and 3 were about 191-, 5.5- and 14500 -fold greater than that of the underivatised quercetin, respectively. Thus, structurally modified quercetin analogues (1, 2 and 3) could afford significantly larger $k$ values than the parent quercetin. The $k$ value for 3 is the largest among the quercetin analogues examined in this study. The $\mathrm{GO}^{\circ}$-scavenging activity of 3 is about 2600 -fold larger than that of 2 . The large difference in $k$ values between 2 and 3 demonstrates that the radical-scavenging activity of the quercetin derivatives largely depends on the position of the methyl group. The $k$ values of aurone derivative 17 and dimethylcatechin 6 were 7.2 $\mathrm{M}^{-1} \mathrm{~s}^{-1}$ and $1.1 \times 10^{3} \mathrm{M}^{-1} \mathrm{~s}^{-1}$, respectively, indicating that delocalisation of the radical cation might operate a high radicalscavenging activity. The delocalisation of radical cation of 6 and $\mathbf{1 7}$ may remain limited to the catechol moiety, and these radical cations may not be delocalised throughout the entire molecule.

IPs and energy difference values $\left(D_{\mathrm{HT}}\right.$, HT: hydrogen transfer) between quercetins and the corresponding phenoxyl radicals, which equal the $\mathrm{O}-\mathrm{H}$ bond dissociation energies (BDE) of their phenolic hydroxy groups, were calculated to elucidate the effect of the methyl groups in the quercetin analogues on their radical-scavenging activity by the density functional theory (DFT). As shown in Fig. 1, phenolic compounds scavenge radicals via two mechanisms. Thus, the IP and $D_{\mathrm{HT}}$ values are reliable parameters to distinguish these two different radicalscavenging mechanisms. If the phenolic compound scavenges

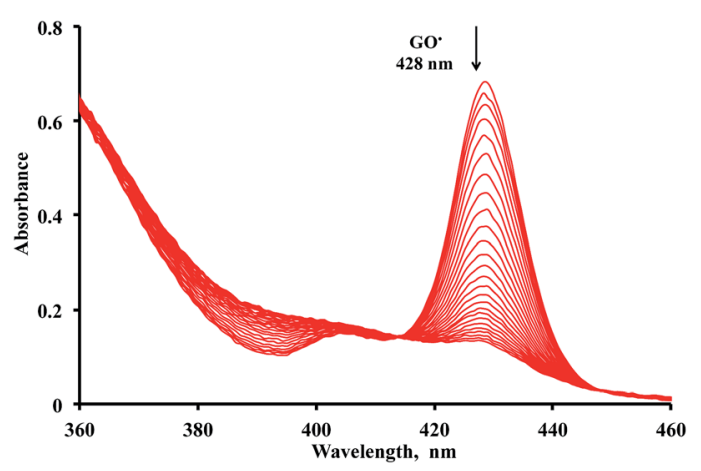

Fig. 3 Spectral change (interval: $4 \mathrm{~s}$ ) observed during the reaction between $2\left(4.7 \times 10^{-5} \mathrm{M}\right)$ and $\mathrm{GO}^{\cdot}\left(4.7 \times 10^{-6} \mathrm{M}\right)$ in deaerated $\mathrm{MeCN}$ at $298 \mathrm{~K}$

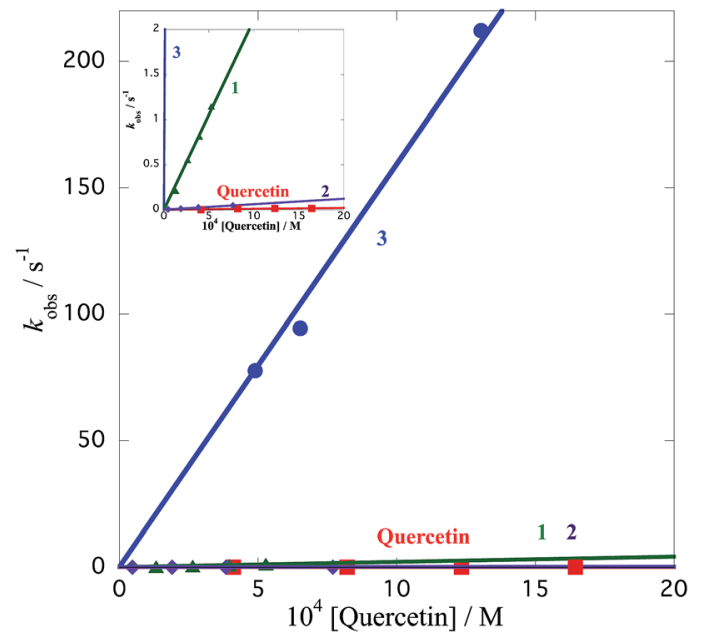

Fig. 4 Plots of the pseudo-first-order rate constant $\left(k_{\text {obs }}\right)$ vs. the concentrations of 1 (green triangles), 2 (purple diamonds), 3 (blue circles) and quercetin (red squares) for radical-scavenging reaction against $\mathrm{GO}^{\circ}$. Inset: enlargement of the same plots from $k_{\text {obs }}$ values of 0 to 2 .

$\mathrm{GO}^{\circ}$ via a one-step hydrogen-atom transfer reaction, i.e., route $\mathrm{B}$, the compound with lower $D_{\mathrm{HT}}$ value exhibit the higher radicalscavenging activity. In contrast, the reactivity of the electrontransfer reaction of phenolic compounds, i.e., route $\mathrm{A}$, is related to the IP values. Because, the lower of the IP, the easier is the electron abstraction. The $D_{\mathrm{HT}}$ and IP values of quercetin analogues were determined by DFT calculations at the B3LYP/6$31 \mathrm{G}(\mathrm{d})$ level and the results are shown in Table 1 . The IP value of 3, which exhibits a markedly enhanced radical-scavenging activity, was the lowest among all the quercetin analogues. Therefore, the mechanism of radical-scavenging of 3 may occur via an electron transfer followed by proton transfer. If the radical-scavenging mechanism of 3 is a one-step hydrogen atom-transfer reaction, the $D_{\mathrm{HT}}$ value at the $4^{\prime}-\mathrm{OH}$ position should be the lowest among all the quercetin analogues. However, the $D_{\mathrm{HT}}$ value of 3 is higher than that of 1 . Thus, enhancement of the radical-scavenging activity of 3 may be the result of electron donation by the introduced methyl group.

We also evaluated the most stable structures of quercetin and quercetin analogues by DFT calculations, as shown in Fig. 5. Quercetin exhibits a coplanar structure between the $4 \mathrm{H}$ curomen (AC rings) and catechol (B ring) moieties (Fig. 5a). In

Table 1 The $D_{\mathrm{HT}}$ and IP values for quercetin analogues

\begin{tabular}{|c|c|c|c|c|}
\hline \multirow{2}{*}{ (1) } & \multirow[b]{2}{*}{$k\left(\mathrm{M}^{-1} \mathrm{~s}^{-1}\right)$} & \multicolumn{2}{|c|}{$D_{\text {HT }}\left(\mathrm{kcal} \mathrm{mol}^{-1}\right)$} & \multirow[b]{2}{*}{ IP $(\mathrm{eV})$} \\
\hline & & $3^{\prime}-\mathrm{OH}$ & $4^{\prime}-\mathrm{OH}$ & \\
\hline 1 & $2.1 \times 10^{3}$ & 390.02 & 388.58 & 6.84 \\
\hline 2 & $6.1 \times 10$ & 390.19 & 390.46 & 6.92 \\
\hline 3 & $1.5 \times 10^{5}$ & 392.91 & 389.10 & 6.80 \\
\hline Quercetin & $1.1 \times 10$ & 397.17 & 390.44 & 6.88 \\
\hline
\end{tabular}


a
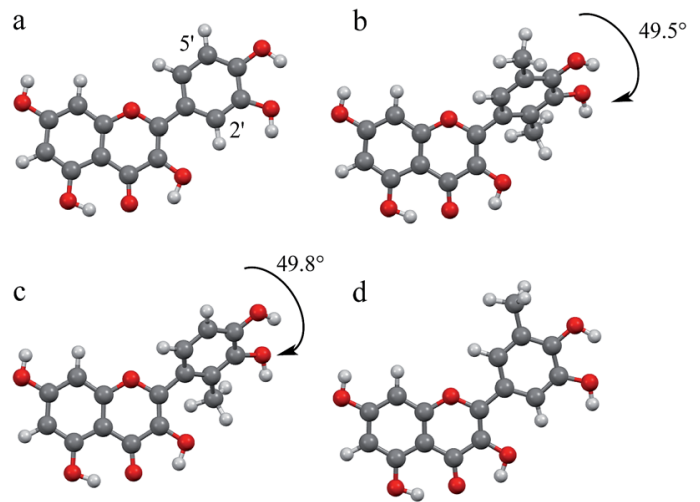

Fig. 5 DFT optimised structures of (a) quercetin, (b) 1, (c) 2, and (d) 3 calculated using DFT (B3LYP/6-31G(d) level).

contrast to the structure of quercetin, analogues $\mathbf{1}$ and 2, which contain methyl groups at the 2 '-position, exhibit a twisted structure between the $\mathrm{AC}$ and $\mathrm{B}$ rings due to steric hindrance of the hydroxyl group of the $\mathrm{C}$ ring. The torsional angles between the AC and B rings of 1 and 2 were $49.5^{\circ}$ and $49.8^{\circ}$, respectively (Fig. 5b and c). On the other hand, 3, which exhibited the highest radical-scavenging activity, formed a coplanar structure similar to the parent quercetin (Fig. $5 \mathrm{~d}$ ). The planar structure of quercetin was maintained even after introduction of a methyl group at the $5^{\prime}$-position. When 3 gives an electron to $\mathrm{GO}^{*}$ to produce the corresponding radical cation of 3 , the planar structure allows for delocalisation of the radical cation throughout the entire molecule, resulting in enhanced radicalscavenging activity. The hydrogen transfer from 3 to $\mathrm{GO}^{\bullet}$ proceeded via electron transfer from 3 to $\mathrm{GO}^{*}$ followed by proton transfer from the resultant radical cation intermediate $3^{\cdot+}$ to the one-electron reduced species of $\mathrm{GO}^{*}$, i.e. $\mathrm{GO}^{-}$. Thus, enhancement of the radical-scavenging activity of 3 is thought to be due to the introduction of an electron-donating methyl group into the catechol moiety. In addition, the planar structure of 3 promoted the enhancement of radical-scavenging activity by stabilisation of $3^{{ }^{+}}$. The structure of synthetic analogues $\mathbf{1}, 2$ exhibited a twisted structure by introduction of methyl group at 2 -position. As a result, the radical cation, which was generated by radical-scavenging reaction, was not able to be delocalised throughout the entire molecule. On the other hands, introduction of methyl group at $5^{\prime}$-position did not affect the planar structure. Thus, the quercetin analogue with methyl group at $5^{\prime}$ position exhibited the highest radical-scavenging activity because delocalised radical cation might be stabilised efficiently by the electron-donating methyl group.

\section{Conclusion}

In this study, we designed and synthesised quercetin analogues to enhance radical-scavenging activity of quercetin. The radicalscavenging activity of quercetin, which scavenges free radicals via the electron-transfer process, was enhanced by the introduction of an electron-donating methyl group into the catechol moiety in the quercetin molecule. Although a single methyl group was introduced into both 2 and 3, the radical-scavenging activities of both quercetin derivatives varied greatly as a result of the different positions of the introduced methyl group. The radical-scavenging activity of $\mathbf{3}$ was enhanced by the electron donating effect. In addition, the radical cation of $\mathbf{3}$ was found to be stabilised by the planar structure between the AC and B rings. The significant enhancement in radical-scavenging activity observed for $\mathbf{3}$ was due to both the electron-donating effect and the planar quercetin structure. Results reported herein suggest that future design and synthesis of novel antioxidant agents with enhanced radical-scavenging activities should consider not only the introduction of electron-donating groups but also stabilisation of radical cations by to flatten throughout the entire molecule. The 3 with high radical-scavenging activity would also be studied not only radical-scavenging activity but also physiological effects of quercetin such as anti-inflammatory and anticancer.

\section{Experimental section}

\section{General methods}

Unless otherwise noted, all commercially available compounds were used as provided without further purification. Solvents for chromatography were technical grade, and acetonitrile for antioxidant activity measurements was analytical grade. Proton $\left({ }^{1} \mathrm{H}\right)$ NMR spectra and $\left({ }^{13} \mathrm{C}\right)$ NMR spectra were recorded on a JEOL JNMAL-400 (400 MHz) instrument and JNM-ECX-500 $(500 \mathrm{MHz})$. Chemical shifts $(\delta)$ are given in parts per million $(\mathrm{ppm})$ and are referenced to residual protonated solvent $\left(\mathrm{CHCl}_{3}\right.$ : $\delta H 7.26 \mathrm{ppm}, \delta C 77.16 \mathrm{ppm} ; \mathrm{CH}_{3} \mathrm{OH}: \delta H 3.31 \mathrm{ppm}, \delta C$ 49.00 ppm; $\left(\mathrm{CH}_{3}\right)_{2} \mathrm{CO}: \delta H 2.05$ ppm, $\delta C 29.84$ ppm; $\left(\mathrm{CH}_{3}\right)_{2} \mathrm{SO}$ : $\delta H 2.50 \mathrm{ppm}, \delta C 39.52 \mathrm{ppm}) . J$ values are given in Hz. Mass spectra were obtained FAB mode with $m$-nitrobenzyl alcohol as a matrix. The progress of all reactions was monitored by thinlayer chromatography (TLC) on silica gel $60 \mathrm{~F}_{254}(0.25 \mathrm{~nm}$, Merck). Column chromatography was performed on silica gel 60 (0.063-0.200 mm, Merck).

3,4-Bis(benzyloxy)-2,5-dimethylbenzaldehyde (9a). Magnesium chloride anhydrous (1.94 g, $20.4 \mathrm{mmol}$ ) and paraformaldehyde $(1.52 \mathrm{~g})$ were added to a solution of 2,5 -xylenol $(1.74 \mathrm{~g}, 14.3 \mathrm{mmol})$ in dry acetonitrile $(9 \mathrm{~mL})$, followed by the dropwise addition of triethylamine $(5.45 \mathrm{~mL})$. After stirring at $100{ }^{\circ} \mathrm{C}$ for $3 \mathrm{~h}$, the mixture was cooled in ice and the solution was diluted with diethyl ether, washed with $1 \mathrm{~N} \mathrm{HCl}$, dried over sodium sulfate, filtered, and evaporated under reduced pressure to afford compound 12. 30\% of hydrogen peroxide (1.35 $\mathrm{mL})$ and $\mathrm{H}_{2} \mathrm{O}(1 \mathrm{~mL})$ were added to solution of 12 and $5 \mathrm{M}$ of sodium hydroxide $(3.24 \mathrm{~mL})$ in THF $(5.45 \mathrm{~mL})$, and the mixture was stirred at $\mathrm{rt}$ for $15 \mathrm{~min}$, the mixture was diluted with diethyl ether, washed with $2 \mathrm{~N} \mathrm{HCl}$, dried over sodium sulfate, filtered, and evaporated under reduced pressure to afford 11. Aluminum(III) chloride (3.82 g, $28.6 \mathrm{mmol}$ ) was slowly added to a solution of 11 and triethyl orthoformate $(2.3 \mathrm{~mL}, 13.86 \mathrm{mmol})$ in dry toluene $(25 \mathrm{~mL})$, and the mixture was stirred at $60{ }^{\circ} \mathrm{C}$ for $3 \mathrm{~h} .3 \mathrm{~N}$ hydrochloric acid was added, and the reaction mixture was further stirred at rt for $1 \mathrm{~h}$. Ethyl acetate was then added, the reaction mixture was filtered, and filtrate was evaporated 
under reduced pressure. The resulting residue was dissolved in ethyl acetate, washed with brine, dried over sodium sulfate filtered, and evaporated under reduced pressure. Since NMR and MS analyses of the residue showed the formation of 13, the crude material was subjected to the next reaction without purification. Benzyl bromide (3.55 mL, $29.84 \mathrm{mmol}$ ) was added dropwise to a solution of crude 13 , potassium carbonate $(6.1 \mathrm{~g}$, 44.14) in dry DMF (15 mL), and the mixture was stirred at rt for $13 \mathrm{~h}$. The solution was diluted with ethyl acetate, washed with brine, and dried over sodium sulfate. After removal of the solvent under reduced pressure, the residue was purified by column chromatography on silica gel (10:1 n-hexane-ethylacetate) to give $1.61 \mathrm{~g}$ (total yield from 2,5-xylenol: $33 \%$ ) of compound 9a as yellow liquid; ${ }^{1} \mathrm{H}-\mathrm{NMR}\left(\mathrm{CDCl}_{3}\right)^{29} \delta 2.23(\mathrm{~s}, 3 \mathrm{H})$, $2.53(\mathrm{~s}, 3 \mathrm{H}), 4.98(\mathrm{~s}, 2 \mathrm{H}), 5.10(\mathrm{~s}, 2 \mathrm{H}), 7.33-7.44(\mathrm{~m}, 11 \mathrm{H}), 10.15$ $(\mathrm{s}, 1 \mathrm{H}) ;{ }^{13} \mathrm{C}-\mathrm{NMR}\left(\mathrm{CDCl}_{3}\right) \delta 11.2,16.0,74.6,74.9,128.1,128.3$, 128.3 , 128.4, 128.4, 130.0, 130.4, 130.4, 136.8, 150.4, 155.3, 191.7; HR-MS (ESI) calcd for $\mathrm{C}_{23} \mathrm{H}_{23} \mathrm{O}_{3}[\mathrm{M}+\mathrm{H}]^{+}: 347.1687$, found 347.1647.

13: ${ }^{1} \mathrm{H}-\mathrm{NMR}$ (acetone- $\left.d_{6}\right) \delta 2.24(\mathrm{~s}, 3 \mathrm{H}), 2.53(\mathrm{~s}, 3 \mathrm{H}), 5.00(\mathrm{~s}$, $2 \mathrm{H}), 5.11(\mathrm{~s}, 2 \mathrm{H}), 7.34-7.44(\mathrm{~m}, 11 \mathrm{H}), 10.15(\mathrm{~s}, 1 \mathrm{H}) ;[\mathrm{M}-\mathrm{H}]^{-}$ 165.

(((3-Methyl-1,2-phenylene)bis(oxy))bis(methylene))dibenzene (24). To a solution of 3-methylcatechol $(51.9 \mathrm{mg}, 0.40 \mathrm{mmol})$ and benzyl bromide $(142 \mu \mathrm{L}, 1.19 \mathrm{mmol})$ in dry DMF $(540 \mu \mathrm{L})$, $\mathrm{K}_{2} \mathrm{CO}_{3}$ (169 mg, $1.22 \mathrm{mmol}$ ) was added, and stirring overnight at rt. The filtrate was diluted with ethyl acetate, washed with brine, dried over $\mathrm{Na}_{2} \mathrm{SO}_{4}$, filtered and the solvent was evaporated. The resultant solid was purified by column chromatography on silica gel ( $3: 2: 0$ to $4: 3: 1 n$-hexane- $\mathrm{CH}_{2} \mathrm{Cl}_{2}$-ethyl acetate) to give $118 \mathrm{mg}$ (97\%) of 24 as white solid; mp 49-50 ${ }^{\circ} \mathrm{C} ;{ }^{1} \mathrm{H}-\mathrm{NMR}$ $\left(\mathrm{CDCl}_{3}\right) \delta 2.24(\mathrm{~s}, 3 \mathrm{H}), 5.00(\mathrm{~s}, 2 \mathrm{H}), 5.11(\mathrm{~s}, 2 \mathrm{H}), 6.79(\mathrm{~d}, J=$ $8.0 \mathrm{~Hz}, 1 \mathrm{H}), 6.84(\mathrm{~d}, J=8.0 \mathrm{~Hz}, 1 \mathrm{H}), 6.93(\mathrm{t}, J=8.0 \mathrm{~Hz}, 1 \mathrm{H}) 7.27$ $(\mathrm{m}, 10 \mathrm{H}) ;{ }^{13} \mathrm{C}-\mathrm{NMR}\left(\mathrm{CDCl}_{3}\right) \delta 16.2,70.8,74.4,112.0,123.3$, $123.7,127.4,127.8,127.9,128.1,128.3,128.3$, 128.5, 132.6, 137.2, 137.9, 146.7, 151.9; HR-MS (ESI) calcd for $\mathrm{C}_{21} \mathrm{H}_{21} \mathrm{O}_{2}[\mathrm{M}+$ $\mathrm{H}]^{+}: 305.1542$, found 305.1520 .

3,4-Bis(benzyloxy)-2-methylbenzaldehyde (9b). The mixture of $N$-methylformanilide (10 mL, $171 \mathrm{mmol}$ ) and phosphoryl chloride $(4.50 \mathrm{~mL}, 48.3 \mathrm{mmol})$ was stirred for $30 \mathrm{~min}$ at $0{ }^{\circ} \mathrm{C}$ to $\mathrm{rt}$ under Ar. After complex was deposited, o-dichlorobenzene (2.64 $\mathrm{mL}$ ) and benzylated 3-methyl catechol 24 were added, and then stirred at $70{ }^{\circ} \mathrm{C}$ for $5.25 \mathrm{~h}$. After sodium acetate solution was added to stop the reaction, $o$-dichlorobenzene was evaporated. The reaction mixture was diluted with ethyl acetate, washed with $0.5 \mathrm{~N}$ of $\mathrm{HCl}$, dried over $\mathrm{Na}_{2} \mathrm{SO}_{4}$, filtered and the solvent was evaporated. The reaction mixture was purified by column chromatography on silica gel (5:1 n-hexane-ethyl acetate) to give $2.43 \mathrm{~g}(44 \%)$ of $9 \mathrm{~b}$ as white solid; mp 92-94 ${ }^{\circ} \mathrm{C} ;{ }^{1} \mathrm{H}-\mathrm{NMR}$ $\left(\mathrm{CDCl}_{3}\right) \delta 2.55(\mathrm{~s}, 3 \mathrm{H}), 4.96(\mathrm{~s}, 2 \mathrm{H}), 5.21(\mathrm{~s}, 2 \mathrm{H}), 6.98(\mathrm{~d}, J=$ $8.5 \mathrm{~Hz}, 1 \mathrm{H}), 7.31-7.46$ (m, 10H), 7.58 (d, $J=8.5 \mathrm{~Hz}, 1 \mathrm{H}), 10.10$ (s, $1 \mathrm{H}) ;{ }^{13} \mathrm{C}-\mathrm{NMR}\left(\mathrm{CDCl}_{3}\right) \delta 11.5,70.6,74.7,110.5,127.5,128.1$, $128.3,128.4,128.5,128.7,129.8,135.5,136.0$, 137.2, 146.4, 156.5, 191.5; HR-MS (ESI) calcd for $\mathrm{C}_{22} \mathrm{H}_{21} \mathrm{O}_{3}[\mathrm{M}+\mathrm{H}]^{+}$: 333.14907, found 333.14835.

2-(Benzyloxy)-6-methylphenol (25). ${ }^{43,44}$ To a solution of 3methylcatechol (1.08 g, $8.73 \mathrm{mmol})$ and benzyl bromide (1.14
$\mathrm{mL}, 9.61 \mathrm{mmol})$ in dry DMF $(10 \mathrm{~mL})$ and dry acetone $(4 \mathrm{~mL})$, $\mathrm{K}_{2} \mathrm{CO}_{3}(3.70 \mathrm{~g}, 26.2 \mathrm{mmol}$ ) was added, and stirring for $4 \mathrm{~h}$ at rt. The filtrate was diluted with diethyl ether, washed with $1 \mathrm{~N}$ of $\mathrm{HCl}$, dried over $\mathrm{Na}_{2} \mathrm{SO}_{4}$, filtered and the solvent was evaporated. The resultant solid was purified by column chromatography on silica gel (7:1 $n$-hexane-ethyl acetate) to give $338 \mathrm{mg}(18 \%)$ of 25 as white solid; mp 51-52 ${ }^{\circ} \mathrm{C} ;{ }^{1} \mathrm{H}-\mathrm{NMR}\left(\mathrm{CDCl}_{3}\right) \delta 2.30(\mathrm{~s}, 3 \mathrm{H})$, $4.85(\mathrm{~s}, 2 \mathrm{H}), 5.55(\mathrm{~s}, 1 \mathrm{H}), 6.69(\mathrm{dd}, J=1.2,8.0 \mathrm{~Hz}, 1 \mathrm{H}), 6.76(\mathrm{dd}, J$ $=1.2,8.0 \mathrm{~Hz}, 1 \mathrm{H}), 6.89(\mathrm{t}, J=8.0 \mathrm{~Hz}, 1 \mathrm{H}), 7.30-7.41(\mathrm{~m}, 5 \mathrm{H}),{ }^{13} \mathrm{C}-$ NMR $\left(\mathrm{CDCl}_{3}\right) \delta 15.4,71.1,109.7,119.1,123.5,124.2,127.7$, 128.3, 128.7, 136.5, 144.0, 145.4; HR-MS (ESI) calcd for $\mathrm{C}_{14} \mathrm{H}_{14} \mathrm{O}_{2}$ $[\mathrm{M}]^{+}:$214.0994, found 214.0978.

3-(Benzyloxy)-4-hydroxy-5-methylbenzaldehyde (26). ${ }^{43,44}$ To a solution of compound $25(1.07 \mathrm{~g}, 5.00 \mathrm{mmol})$ in acetic acid (33 $\mathrm{mL})$, hexamethylenetetramine $(1.76 \mathrm{~g}, 12.51 \mathrm{mmol})$ was added. The resulting solution was stirred at $100{ }^{\circ} \mathrm{C}$ for 4 days under Ar. The reaction mixture was added saturated aqueous solution of $\mathrm{NaHCO}_{3}$ and extracted with $\mathrm{CH}_{2} \mathrm{Cl}_{2}$. The organic phase was dried over $\mathrm{Na}_{2} \mathrm{SO}_{4}$, filtered and the solvent was evaporated. The residue was purified by column chromatography on silica gel (7 : $1 n$-hexane-ethyl acetate) to give $676.4 \mathrm{mg}$ (56\%) of 26 as white solid; mp $113-114{ }^{\circ} \mathrm{C} ;{ }^{1} \mathrm{H}-\mathrm{NMR}$ (acetone- $\left.d_{6}\right) \delta 2.28(\mathrm{~s}, 3 \mathrm{H})$, 5.25 (s, 2H), 7.36-7.51 (m, 7H), 8.69 (brs, 1H), $9.77(\mathrm{~s}, 1 \mathrm{H}){ }^{13} \mathrm{C}-$ NMR $\left(\mathrm{CDCl}_{3}\right) \delta 15.4,71.1,109.9,125.2,127.9,128.6,128.6$, 129.0, 129.3, 137.2, 147.0, 151.2, 190.8; HR-MS (ESI) calcd for $\mathrm{C}_{15} \mathrm{H}_{15} \mathrm{O}_{3}[\mathrm{M}+\mathrm{H}]^{+}:$243.1021, found 243.1071.

3,4-Bis(benzyloxy)-5-methylbenzaldehyde (9c). To a solution of compound $26(654.8 \mathrm{mg}, 2.70 \mathrm{mmol})$ and benzyl bromide $(386 \mu \mathrm{L}, 3.24 \mathrm{mmol})$ in dry DMF $(2 \mathrm{~mL}), \mathrm{K}_{2} \mathrm{CO}_{3}$ (451.9 mg, 3.24 $\mathrm{mmol}$ ) was added, and stirring for $13 \mathrm{~h}$ at $\mathrm{rt}$. The filtrate was diluted with $\mathrm{CH}_{2} \mathrm{Cl}_{2}$, washed with water, dried over $\mathrm{Na}_{2} \mathrm{SO}_{4}$, filtered and the solvent was evaporated. The resultant solid was purified by column chromatography on silica gel $(10: 1 n$ hexane-ethyl acetate) to give $841 \mathrm{mg}(94 \%)$ of $9 \mathrm{c}$ as white solid; mp 62-64 ${ }^{\circ} \mathrm{C} ;{ }^{1} \mathrm{H}-\mathrm{NMR}\left(\mathrm{CD}_{3} \mathrm{OD}\right)^{46,47} \delta 2.24(\mathrm{~s}, 3 \mathrm{H}), 5.14(\mathrm{~s}, 2 \mathrm{H})$, $5.27(\mathrm{~s}, 2 \mathrm{H}), 7.29-7.44(\mathrm{~m}, 9 \mathrm{H}), 7.51(\mathrm{~d}, J=2.0 \mathrm{~Hz}, 1 \mathrm{H}), 7.57-7.58$ $(\mathrm{m}, 2 \mathrm{H}), 9.87(\mathrm{~s}, 1 \mathrm{H}) ;{ }^{13} \mathrm{C}-\mathrm{NMR}\left(\mathrm{CD}_{3} \mathrm{OD}\right) \delta 16.4,71.3,74.9,111.6$, $127.1,128.7$, 128.8, 128.8, 129.1, 129.3, 129.3, 133.4, 133.7, 137.8, 138.5, 152.4, 153.2, 191.7; HR-MS $\left(\mathrm{FAB}^{+}\right)$calcd for $\mathrm{C}_{22} \mathrm{H}_{21} \mathrm{O}_{3}[\mathrm{M}+\mathrm{H}]^{+}:$333.1491, found 333.1507.

1-(2,4,6-Tris(methoxymethoxy)phenyl)ethan-1-one (19). The compound 19 was prepared in analogy to a procedure by Yang et al., ${ }^{40}$ Pandurangan $e t ~ a l .{ }^{39}$ and Jiang et al. ${ }^{38}$ A solution of $2^{\prime}, 4^{\prime}, 6^{\prime}$-trihydroxyacetophenone monohydrate $(4.00 \mathrm{~g}, 21.8$ $\mathrm{mmol})$ in dry DMF $(10 \mathrm{~mL})$ was added dropwise to a suspension of sodium hydride $(5.23 \mathrm{~g}, 109 \mathrm{mmol})$ in $\mathrm{CH}_{2} \mathrm{Cl}_{2}(45 \mathrm{~mL})$ at $0{ }^{\circ} \mathrm{C}$. Chloromethyl methyl ether $(8.20 \mathrm{~mL}, 109 \mathrm{mmol})$ was added dropwise to a reaction mixture and then stirred for overnight at rt. The reaction mixture was quenched by adding water and extracted with $\mathrm{CH}_{2} \mathrm{Cl}_{2}$. The organic solution was washed with 1 $\mathrm{N}$ of $\mathrm{HCl}$, dried over $\mathrm{Na}_{2} \mathrm{SO}_{4}$, filtered and the solvent was evaporated. The residue was purified by column chromatography on silica gel ( $1: 3$ ethyl acetate- $n$-hexane) to give $2.81 \mathrm{~g}$ (43\%) of 19 as white solid; $\mathrm{mp} 37-38{ }^{\circ} \mathrm{C} ;{ }^{1} \mathrm{H}-\mathrm{NMR}\left(\mathrm{CDCl}_{3}\right) \delta 2.50$ $(\mathrm{s}, 3 \mathrm{H}), 3.46(\mathrm{~s}, 9 \mathrm{H}), 5.14(\mathrm{~s}, 6 \mathrm{H}), 6.51(\mathrm{~s}, 2 \mathrm{H}) ;{ }^{13} \mathrm{C}-\mathrm{NMR}\left(\mathrm{CDCl}_{3}\right)$ $\delta 32.5,56.2,56.3,94.4,94.7,96.9,116.8,155.1,159.4,201.4$; HRMS (ESI) calcd for $\mathrm{C}_{14} \mathrm{H}_{21} \mathrm{O}_{7}[\mathrm{M}+\mathrm{H}]^{+}: 301.1287$, found 301.1267 . 
(E)-3-(3,4-Bis(benzyloxy)-2,5-dimethylphenyl)-1-(2,4,6-tris (methoxymethoxy)phenyl)prop-2-en-1-one (20a). To a stirred solution of 19 (723 mg, $2.39 \mathrm{mmol}$ ) and 9a (981 $\mathrm{mg}, 2.83 \mathrm{mmol}$ ) in dry DMF $(1 \mathrm{~mL})$ at $\mathrm{rt}$ under $\mathrm{Ar}$, ethanol $(6 \mathrm{~mL})$ and $40 \%$ aqueous potassium hydroxide $(2.2 \mathrm{~mL})$ were added. The resulting solution was stirred at rt for $18.5 \mathrm{~h}$, the solution was diluted with ethyl acetate, washed with brain. The organic phase was dried over $\mathrm{Na}_{2} \mathrm{SO}_{4}$, filtered and the solvent was evaporated. The residue was purified by column chromatography on silica gel ( $3: 1$ to $2: 1 n$-hexane-ethyl acetate) to give $1.26 \mathrm{~g}(85 \%)$ of chalcone structure $20 \mathrm{a}$ as yellow liquid; ${ }^{1} \mathrm{H}-\mathrm{NMR}$ $\left(\mathrm{CDCl}_{3}\right) \delta 2.21(\mathrm{~s}, 3 \mathrm{H}), 2.21(\mathrm{~s}, 3 \mathrm{H}), 3.41(\mathrm{~s}, 6 \mathrm{H}), 3.46(\mathrm{~s}, 3 \mathrm{H}), 4.96$ $(\mathrm{s}, 2 \mathrm{H}), 5.03(\mathrm{~s}, 2 \mathrm{H}), 5.12(\mathrm{~s}, 4 \mathrm{H}), 5.18(\mathrm{~s}, 2 \mathrm{H}), 6.57(\mathrm{~s}, 2 \mathrm{H}), 6.83$ $(\mathrm{d}, J=16.0 \mathrm{~Hz}, 1 \mathrm{H}), 7.25(\mathrm{~s}, 1 \mathrm{H}), 7.32-7.41(\mathrm{~m}, 10 \mathrm{H}), 7.63(\mathrm{~d}, J=$ $16.0 \mathrm{~Hz}, 1 \mathrm{H}) ;{ }^{13} \mathrm{C}-\mathrm{NMR}\left(\mathrm{CDCl}_{3}\right) \delta 12.1,16.2,56.2,56.3,56.3$, 74.8, 74.9, 94.5, 94.7, 94.7, 97.0, 97.2, 115.1, 124.5, 128.1, 128.4, $128.4,128.4,128.5,129.2,130.0,130.2,130.8,137.2,137.3$, 142.3 150.4 152.2, 155.8, 159.4, 159.6, 194.0; HR-MS (ESI) calcd for $\mathrm{C}_{37} \mathrm{H}_{41} \mathrm{O}_{9}[\mathrm{M}+\mathrm{H}]^{+}$: 629.2751, found 629.2786.

(E)-3-(3,4-Bis(benzyloxy)-2-methylphenyl)-1-(2,4,6-tris(methoxymethoxy)phenyl)prop-2-en-1-one (20b). To a stirred solution of 19 (893 $\mathrm{mg}, 2.93 \mathrm{mmol})$ and $9 \mathrm{~b}(1.17 \mathrm{~g}, 3.52 \mathrm{mmol})$ in dry DMF $(1.3 \mathrm{~mL})$ at rt under Ar, ethanol $(7.4 \mathrm{~mL})$ and $40 \%$ aqueous potassium hydroxide $(2.7 \mathrm{~mL})$ were added. The resulting solution was stirred at rt for $46 \mathrm{~h}$, the solution was diluted with ethyl acetate, washed with brain. The organic phase was dried over $\mathrm{Na}_{2} \mathrm{SO}_{4}$, filtered and the solvent was evaporated. The residue was purified by column chromatography on silica gel $(3: 1$ to $1: 1 n$-hexane-ethyl acetate) to give $1.67 \mathrm{~g}$ (91\%) of chalcone structure 20b as yellow liquid; ${ }^{1} \mathrm{H}-\mathrm{NMR}\left(\mathrm{CDCl}_{3}\right) \delta 2.21(\mathrm{~s}, 3 \mathrm{H})$, $3.39(\mathrm{~s}, 6 \mathrm{H}), 3.49(\mathrm{~s}, 3 \mathrm{H}), 4.95(\mathrm{~s}, 2 \mathrm{H}), 5.11(\mathrm{~s}, 4 \mathrm{H}), 5.16(\mathrm{~s}, 2 \mathrm{H})$, $5.17(\mathrm{~s}, 2 \mathrm{H}), 6.56(\mathrm{~s}, 2 \mathrm{H}), 6.82(\mathrm{~d}, J=16.0 \mathrm{~Hz}, 1 \mathrm{H}), 6.88(\mathrm{~d}, J=$ $9.0 \mathrm{~Hz}, 1 \mathrm{H}), 7.30-7.46(\mathrm{~m}, 11 \mathrm{H}), 7.63(\mathrm{~d}, J=16.0 \mathrm{~Hz}, 1 \mathrm{H}) ;{ }^{13} \mathrm{C}-$ NMR $\left(\mathrm{CDCl}_{3}\right) \delta 12.2,56.3,70.6,74.6,94.5,94.6,97.1,111.4$, $115.1,123.0$, 127.4, 127.5, 128.0, 128.1, 128.3, 128.4, 128.6, 133.0, 136.5, 137.4, 142.5, 146.4, 153.4, 155.8, 159.5, 194.1; HRMS $\left(\mathrm{FAB}^{+}\right)$calcd for $\mathrm{C}_{36} \mathrm{H}_{39} \mathrm{O}_{9}[\mathrm{M}+\mathrm{H}]^{+}$: 615.2581, found 615.2594 .

(E)-3-(3,4-Bis(benzyloxy)-5-methylphenyl)-1-(2,4,6-tris(methoxymethoxy)phenyl)prop-2-en-1-one (20c). To a stirred solution of 19 (477 mg, $1.55 \mathrm{mmol})$ and $9 \mathrm{c}(620 \mathrm{mg}, 1.86 \mathrm{mmol})$ in dry DMF $(672 \mu \mathrm{L})$ at $\mathrm{rt}$ under Ar, ethanol $(3.9 \mathrm{~mL})$ and $40 \%$ aqueous potassium hydroxide $(1.4 \mathrm{~mL})$ were added. The resulting solution was stirred at $\mathrm{rt}$ for $18.5 \mathrm{~h}$, the solution was diluted with ethyl acetate, washed with brain. The organic phase was dried over $\mathrm{Na}_{2} \mathrm{SO}_{4}$, filtered and the solvent was evaporated. The residue was purified by column chromatography on silica gel ( $4: 1$ to $2: 1 n$-hexane-ethyl acetate) to give $838 \mathrm{mg}(86 \%)$ of chalcone structure $20 \mathrm{c}$ as yellow liquid; ${ }^{1} \mathrm{H}$ NMR $\left(\mathrm{CDCl}_{3}\right) \delta 2.20(\mathrm{~s}, 3 \mathrm{H}), 3.38(\mathrm{~s}, 6 \mathrm{H}), 3.51(\mathrm{~s}, 3 \mathrm{H}), 5.04(\mathrm{~s}$, $2 \mathrm{H}), 5.11(\mathrm{~s}, 4 \mathrm{H}), 5.13(\mathrm{~s}, 2 \mathrm{H}), 5.18(\mathrm{~s}, 2 \mathrm{H}), 6.57(\mathrm{~s}, 2 \mathrm{H}), 6.85(\mathrm{~d}, J$ $=16.0 \mathrm{~Hz}, 1 \mathrm{H}), 6.96(\mathrm{~d}, J=1.0 \mathrm{~Hz}, 1 \mathrm{H}), 7.04(\mathrm{~d}, J=2.0 \mathrm{~Hz}, 1 \mathrm{H})$, $7.25(\mathrm{~d}, J=17.0 \mathrm{~Hz}, 1 \mathrm{H}), 7.30-7.46(\mathrm{~m}, 10 \mathrm{H}) ;{ }^{13} \mathrm{C}-\mathrm{NMR}\left(\mathrm{CDCl}_{3}\right)$ $\delta$ 16.3, 56.3, 70.8, 76.7, 94.5, 97.1, 111.0, 114.8, 127.4, 128.0, 128.0 , 128.0, 128.2, 128.3, 128.4, 128.6, 130.3, 132.9, 136.6,
137.4, 145.3, 148.8, 152.0, 155.7, 159.5, 194.3; HR-MS $\left(\mathrm{FAB}^{+}\right)$ calcd for $\mathrm{C}_{36} \mathrm{H}_{39} \mathrm{O}_{9}[\mathrm{M}+\mathrm{H}]^{+}:$615.2638, found 615.2594.

2-(3,4-Bis(benzyloxy)-2,5-dimethylphenyl)-3,5,7-trihydroxychroman-4-one (22a). Methanol (5 mL) and 5.4\% aqueous sodium hydroxide $(5 \mathrm{~mL})$ were added to a solution of 20 a (324 mg, $516 \mu \mathrm{mol}$ ) in 1,4-dioxiane ( $5 \mathrm{~mL}$ ), and then added $30 \%$ hydrogen peroxide solution $(5 \mathrm{~mL})$. The resulting mixture was stirred at rt for $4 \mathrm{~h}$, the solution was diluted with ethyl acetate, washed with water. The organic phase was dried over $\mathrm{Na}_{2} \mathrm{SO}_{4}$, filtered and the solvent was evaporated to afford epoxide intermediate 21a, which was subjected to the next step without purification. $12 \mathrm{~N} \mathrm{HCl}(1 \mathrm{~mL})$ was slowly added to a solution of crude 21a in methanol $(22 \mathrm{~mL})$, and the mixture was refluxed for $1.0 \mathrm{~h}$. The reaction mixture was evaporated, and then the crude material was diluted with ethyl acetate, washed with water. The organic phase was dried over $\mathrm{Na}_{2} \mathrm{SO}_{4}$, filtered and the solvent was evaporated. The residue was purified by column chromatography on silica gel (4:1 n-hexane-ethyl acetate) to give $105 \mathrm{mg}$ (total yield from 20a: 40\%) of 22a as white solid; mp 207-210 ${ }^{\circ} \mathrm{C} ;{ }^{1} \mathrm{H}$-NMR (acetone- $d_{6}$ ) $\delta 2.22(\mathrm{~s}, 3 \mathrm{H}), 2.27(\mathrm{~s}, 3 \mathrm{H})$, $4.36(\mathrm{~m}, 1 \mathrm{H}), 4.89(\mathrm{~d}, J=3.2 \mathrm{~Hz}, 1 \mathrm{H}), 4.96(\mathrm{~s}, 2 \mathrm{H}), 5.00(\mathrm{~s}, 2 \mathrm{H})$, $5.43(\mathrm{~m}, 1 \mathrm{H}), 5.99(\mathrm{~s}, 2 \mathrm{H}), 7.16(\mathrm{~s}, 1 \mathrm{H}), 7.32-7.49(\mathrm{~m}, 10 \mathrm{H}) ;{ }^{13} \mathrm{C}-$ NMR (acetone- $d_{6}$ ) $\delta 11.7,16.1,74.8,75.0,78.4,81.6,95.8,103.4$, 126.9, 128.3, 128.7, 128.8, 129.2, 129.4, 133.2, 128.6, 138.7, 150.3, 150.3, 164.6, 203.1; HR-MS $\left(\mathrm{FAB}^{+}\right)$calcd for $\mathrm{C}_{31} \mathrm{H}_{29} \mathrm{O}_{7}[\mathrm{M}+$ $\mathrm{H}]^{+}:$513.1893, found 513.1913.

21a: ${ }^{1} \mathrm{H}-\mathrm{NMR}$ (acetone- $\left.d_{6}\right) \delta 2.17(\mathrm{~s}, 3 \mathrm{H}), 2.26(\mathrm{~S}, 3 \mathrm{H}), 3.40(\mathrm{~s}$, $6 \mathrm{H}), 3.43(\mathrm{~s}, 3 \mathrm{H}), 3.72(\mathrm{~d}, J=1.5 \mathrm{~Hz}, 1 \mathrm{H}), 4.05(\mathrm{~d}, J=1.5 \mathrm{~Hz}, 1 \mathrm{H})$, $4.99(\mathrm{~s}, 2 \mathrm{H}), 4.99(\mathrm{~s}, 2 \mathrm{H}), 5.16(\mathrm{~s}, 2 \mathrm{H}), 5.20(\mathrm{~s}, 2 \mathrm{H}), 6.57(\mathrm{~s}, 2 \mathrm{H})$, $6.81(\mathrm{~s}, 1 \mathrm{H}), 7.32-7.46(\mathrm{~m}, 10 \mathrm{H}) ;{ }^{13} \mathrm{C}-\mathrm{NMR}$ (acetone- $\left.d_{6}\right) \delta 11.6$, 16.2, 56.3, 56.5, 57.4, 63.9, 75.2, 75.4, 95.1, 95.6, 97.5, 113.5, $122.3,128.7,128.8,129.1,129.2$, 129.5, 130.8, 131.4, 138.5, 138.7, 150.9, 151.2, 157.3, 161.3, 197.4; HR-MS (ESI) calcd for $\mathrm{C}_{37} \mathrm{H}_{41} \mathrm{O}_{10}[\mathrm{M}+\mathrm{H}]^{+}:$645.2700, found 645.2699.

2-(3,4-Bis(benzyloxy)-2-methylphenyl)-3,5,7-trihydroxychroman-4-one (22b). Methanol (2.5 mL) and 5.4\% aqueous sodium hydroxide $(2.5 \mathrm{~mL})$ were added to a solution of $20 \mathrm{~b}(290 \mathrm{mg}, 472$ $\mu \mathrm{mol})$ in 1,4-dioxiane $(7.5 \mathrm{~mL})$, and then added $30 \%$ hydrogen peroxide solution $(2.5 \mathrm{~mL})$. The resulting mixture was stirred at rt for $5 \mathrm{~h}$, the solution was diluted with ethyl acetate, washed with brain. The organic phase was dried over $\mathrm{Na}_{2} \mathrm{SO}_{4}$, filtered and the solvent was evaporated to afford epoxide intermediate 21b, which was subjected to the next step without purification. $12 \mathrm{~N} \mathrm{HCl}(1 \mathrm{~mL})$ was slowly added to a solution of crude $21 \mathbf{b}$ in 1,4-dioxiane $(5 \mathrm{~mL})$ and methanol $(17 \mathrm{~mL})$, and the mixture was stirred at $55{ }^{\circ} \mathrm{C}$ for $1.0 \mathrm{~h}$. The reaction mixture was evaporated, and then the crude material was taken into ethyl acetate, washed with water. The organic phase was dried over $\mathrm{Na}_{2} \mathrm{SO}_{4}$, filtered and the solvent was evaporated. The residue was purified by column chromatography on silica gel (2:1 n-hexaneethyl acetate) to give $230 \mathrm{mg}$ (total yield from 20b: $32 \%$ ) of $22 \mathbf{b}$ as white solid; mp $164-166{ }^{\circ} \mathrm{C} ;{ }^{1} \mathrm{H}-\mathrm{NMR}$ (acetone- $d_{6}$ ) $\delta 2.31$ (s, $3 \mathrm{H}), 4.68(\mathrm{~d}, J=12.0 \mathrm{~Hz}, 1 \mathrm{H}), 4.97(\mathrm{~s}, 2 \mathrm{H}), 5.21$ (s, 2H), 5.40 (d, $J$ $=12.0 \mathrm{~Hz}, 1 \mathrm{H}), 5.89$ (d, $2.0 \mathrm{~Hz}, 1 \mathrm{H}), 5.94(\mathrm{~d}, J=2.5 \mathrm{~Hz}, 1 \mathrm{H}), 7.08$ $(\mathrm{d}, J=9.0 \mathrm{~Hz}, 1 \mathrm{H}), 7.26-7.53(\mathrm{~m}, 11 \mathrm{H}) ;{ }^{13} \mathrm{C}-\mathrm{NMR}$ (acetone- $d_{6}$ ) $\delta$ 12.2, 71.1, 73.2, 75.1, 80.7, 95.9, 97.0, 101.5, 112.1, 124.1, 128.5 , 128.6, 128.7, 129.1, 129.2, 129.3, 129.9, 133.2, 138.3, 
139.0, 147.0, 153.0, 164.3, 164.8, 167.9, 198.3; HR-MS $\left(\mathrm{FAB}^{+}\right)$ calcd for $\mathrm{C}_{30} \mathrm{H}_{27} \mathrm{O}_{7}[\mathrm{M}+\mathrm{H}]^{+}$: 499.1752, found 499.1757.

21b: ${ }^{1} \mathrm{H}-\mathrm{NMR}\left(\mathrm{CDCl}_{3}\right) \delta 2.13(\mathrm{~s}, 3 \mathrm{H}), 3.41(\mathrm{~s}, 6 \mathrm{H}), 3.48(\mathrm{~s}, 3 \mathrm{H})$, $5.08-5.17(\mathrm{~m}, 11 \mathrm{H}), 5.45(\mathrm{~d}, J=1.7 \mathrm{~Hz}, 1 \mathrm{H}), 6.56(\mathrm{~s}, 2 \mathrm{H}), 6.89(\mathrm{~d}$, $J=9.2 \mathrm{~Hz}, 1 \mathrm{H}), 7.30-7.44(\mathrm{~m}, 10 \mathrm{H}), 7.59(\mathrm{~d}, J=9.2 \mathrm{~Hz}, 1 \mathrm{H}) ;{ }^{13} \mathrm{C}-$ NMR $\left(\mathrm{CDCl}_{3}\right) \delta 11.3,56.3,56.5,59.4,70.6,74.6,79.3,94.3,94.9$, 96.9, 110.6, 111.4, 124.7, 127.4, 127.9, 128.3, 128.5, 129.7, 130.6, 136.8, 137.6, 145.8, 151.7, 156.9, 161.1, 199.7; HR-MS $\left(\mathrm{FAB}^{+}\right)$ calcd for $\mathrm{C}_{36} \mathrm{H}_{38} \mathrm{O}_{10}[\mathrm{M}+\mathrm{H}]^{+}: 630.2472$, found 630.2465 .

2-(3,4-Bis(benzyloxy)-5-methylphenyl)-3,5,7-trihydroxychroman-4-one (22c). Methanol $(1.5 \mathrm{~mL})$ and $5.4 \%$ aqueous sodium hydroxide $(1.5 \mathrm{~mL})$ were added to a solution of $20 \mathrm{c}(165 \mathrm{mg}, 269$ $\mu \mathrm{mol})$ in 1,4-dioxiane $(4.3 \mathrm{~mL})$, and then added $30 \%$ hydrogen peroxide solution $(1.5 \mathrm{~mL})$. The resulting mixture was stirred at rt for $1 \mathrm{~h}$, the solution was diluted with ethyl acetate, washed with aqueous sodium thiosulfate and brain. The organic phase was dried over $\mathrm{Na}_{2} \mathrm{SO}_{4}$, filtered and the solvent was evaporated to afford epoxide intermediate 21c, which was subjected to the next step without purification. $12 \mathrm{~N} \mathrm{HCl}(0.5 \mathrm{~mL})$ was slowly added to a solution of crude $21 \mathrm{c}$ in 1,4-dioxiane $(3 \mathrm{~mL})$ and methanol $(10 \mathrm{~mL})$, and the mixture was stirred at $55^{\circ} \mathrm{C}$ for $1.0 \mathrm{~h}$. The reaction mixture was evaporated, and then the crude material was taken into ethyl acetate, washed with water. The organic phase was dried over $\mathrm{Na}_{2} \mathrm{SO}_{4}$, filtered and the solvent was evaporated. The residue was purified by column chromatography on silica gel ( $4: 1$ to $2: 1 n$-hexane-ethyl acetate) to give $33 \mathrm{mg}$ (total yield from 20c: $25 \%$ ) of $22 \mathrm{c}$ as white solid; $\mathrm{mp}$ 120-121 ${ }^{\circ} \mathrm{C} ;{ }^{1} \mathrm{H}-\mathrm{NMR}$ (acetone- $\left.d_{6}\right) \delta 2.24(\mathrm{~s}, 3 \mathrm{H}), 4.70(\mathrm{~d}, 12.0 \mathrm{~Hz}$, $1 \mathrm{H}), 4.77$ (brs, 1H), $5.04(\mathrm{~s}, 2 \mathrm{H}), 5.09$ (d, J = 11.0 Hz, 1H), 5.20 (s, $2 \mathrm{H}), 5.98(\mathrm{~d}, J=1.5 \mathrm{~Hz}, 1 \mathrm{H}), 6.01(\mathrm{~d}, J=2.5 \mathrm{~Hz}, 1 \mathrm{H}), 7.03(\mathrm{~d}, J=$ $1.5 \mathrm{~Hz}, 1 \mathrm{H}), 7.28-7.56(\mathrm{~m}, 11 \mathrm{H}), 9.71$ (brs, $1 \mathrm{H}), 11.71(\mathrm{~s}, 1 \mathrm{H}) ;{ }^{13} \mathrm{C}-$ NMR (acetone- $d_{6}$ ) $\delta 17.3,72.1,73.8,75.5,85.2,96.8,97.9,102.2$, $113.3,124.5,129.3,129.4,129.8,129.9,130.0,133.3,134.4$, 138.9, 139.8, 148.5, 153.4, 164.8, 165.7, 168.5, 196.7; HR-MS $\left(\mathrm{FAB}^{+}\right.$) calcd for $\mathrm{C}_{30} \mathrm{H}_{27} \mathrm{O}_{7}[\mathrm{M}+\mathrm{H}]^{+}:$499.1757, found 499.1756.

21c: ${ }^{1} \mathrm{H}-\mathrm{NMR}\left(\mathrm{CDCl}_{3}\right) \delta 2.20(\mathrm{~s}, 3 \mathrm{H}), 3.36(\mathrm{~s}, 6 \mathrm{H}), 3.46(\mathrm{~s}, 3 \mathrm{H})$, $3.90(\mathrm{~s}, 1 \mathrm{H}), 3.90(\mathrm{~s}, 1 \mathrm{H}), 4.99(\mathrm{~s}, 2 \mathrm{H}), 5.07-5.11(\mathrm{~m}, 4 \mathrm{H}), 5.14(\mathrm{~s}$, $2 \mathrm{H}), 5.17(\mathrm{~s}, 2 \mathrm{H}), 6.53(\mathrm{~s}, 2 \mathrm{H}), 6.78(\mathrm{~s}, 1 \mathrm{H}), 6.84(\mathrm{~d}, J=1.8 \mathrm{~Hz}$, $1 \mathrm{H}), 7.29-7.47(\mathrm{~m}, 10 \mathrm{H}) ;{ }^{13} \mathrm{C}-\mathrm{NMR}\left(\mathrm{CDCl}_{3}\right) \delta 15.6,55.6,55.6$, 58.9, 63.7, 70.1, 73.8, 93.7, 94.3, 96.3, 108.2, 112.0, 120.2, 126.9, $127.4,127.7,127.9,128.0,131.0,132.1,136.3,137.1,146.3$, $151.5,156.5,160.3,195.4$; HR-MS $\left(\mathrm{FAB}^{+}\right)$calcd for $\mathrm{C}_{36} \mathrm{H}_{38} \mathrm{O}_{10}[\mathrm{M}$ $+\mathrm{H}]^{+}: 630.2476$, found 630.2465 .

2-(3,4-Dihydroxy-2,5-dimethylphenyl)-3,5,7-trihydroxy-4Hchromen-4-one (1). A solution of $22 \mathrm{a}(105 \mathrm{mg}, 205 \mu \mathrm{mol})$ in dry THF $(40 \mathrm{~mL})$ was hydrogenated at $\mathrm{rt}$ in the presence of $20 \%$ palladium hydroxide on carbon $(40 \mathrm{mg}$ ). After stirring for approximately $5.5 \mathrm{~h}$, the catalyst was filtered, and the solvent was evaporated to afford 23a, which was subjected to the next step without purification. Dimethyl taxifolin 23a in ethanol (1.5 $\mathrm{mL}$ ) was added to $20 \%$ potassium metabisulphite $(3 \mathrm{~mL})$, and then stirred at $100{ }^{\circ} \mathrm{C}$ for $7 \mathrm{~h}$. The reaction mixture was taken into ice water, the precipitate was filtered to give $21 \mathrm{mg}$ (total yield from 22a: $31 \%$ ) of 1 as yellow solid; $\mathrm{mp}>290{ }^{\circ} \mathrm{C} ;{ }^{1} \mathrm{H}-\mathrm{NMR}$ $\left(\mathrm{CD}_{3} \mathrm{OD}\right) \delta 2.14(\mathrm{~s}, 3 \mathrm{H}), 2.22(\mathrm{~s}, 3 \mathrm{H}), 6.13(\mathrm{~d}, J=2.3 \mathrm{~Hz}, 1 \mathrm{H}), 6.21$ $(\mathrm{d}, J=1.8 \mathrm{~Hz}, 1 \mathrm{H}), 6.80(\mathrm{~s}, 1 \mathrm{H}) ;{ }^{13} \mathrm{C}-\mathrm{NMR}\left(\mathrm{CD}_{3} \mathrm{OD}\right) \delta$ 13.6, 16.0, 94.5, 99.3, 105.1, 123.1, 123.3, 123.9, 124.2, 137.8, 144.5, 146.5,
151.5, 158.9, 162.8, 165.6, 177.8; HR-MS $\left(\mathrm{FAB}^{+}\right)$calcd for $\mathrm{C}_{17} \mathrm{H}_{15} \mathrm{O}_{7}[\mathrm{M}+\mathrm{H}]^{+}:$331.0817, found 331.0818.

2-(3,4-Dihydroxy-2-methylphenyl)-3,5,7-trihydroxy-4Hchromen-4-one (2). A solution of $22 \mathbf{b}(64 \mathrm{mg}, 129 \mu \mathrm{mol})$ in dry THF (12 mL) was hydrogenated at $\mathrm{rt}$ in the presence of $20 \%$ palladium hydroxide on carbon (35 mg). After stirring for approximately $2 \mathrm{~h}$ until TLC showed that the reaction was complete, the catalyst was filtered, and the solvent was evaporated to afford $\mathbf{2 3 b}$, which was subjected to the next step without purification. Dimethyl taxifolin $\mathbf{2 3 b}$ in ethanol $(1 \mathrm{~mL}$ ) was added to $20 \%$ potassium metabisulphite $(2.1 \mathrm{~mL})$, and then stirred at $100{ }^{\circ} \mathrm{C}$ for $5 \mathrm{~h}$. The reaction mixture wad taken into ice water, the precipitate was filtered to give $33.8 \mathrm{mg}$ (total yield from $22 \mathbf{b}$ : $82 \%$ ) of 2 as yellow solid; $\mathrm{mp}>290{ }^{\circ} \mathrm{C} ;{ }^{1} \mathrm{H}-\mathrm{NMR}\left(\mathrm{CD}_{3} \mathrm{OD}\right) \delta 2.16$ $(\mathrm{s}, 3 \mathrm{H}), 6.18(\mathrm{~d}, J=1.6 \mathrm{~Hz}, 1 \mathrm{H}), 6.28(\mathrm{~d}, J=1.2 \mathrm{~Hz}, 1 \mathrm{H}), 7.73(\mathrm{~d}, J$ $=6.8 \mathrm{~Hz}, 1 \mathrm{H}), 6.87(\mathrm{~d}, J=6.8 \mathrm{~Hz}, 1 \mathrm{H}) ;{ }^{13} \mathrm{C}-\mathrm{NMR}\left(\mathrm{CD}_{3} \mathrm{OD}\right) \delta 13.5$, 94.5, 99.3, 105.1, 113.1, 122.4, 123.8, 126.0, 137.9, 144.8, 147.8, 151.4, 158.9, 162.8, 165.6, 177.8; HR-MS $\left(\mathrm{FAB}^{+}\right)$calcd for $\mathrm{C}_{16} \mathrm{H}_{13} \mathrm{O}_{7}[\mathrm{M}+\mathrm{H}]^{+}:$317.0654, found 317.0661.

2-(3,4-Dihydroxy-5-methylphenyl)-3,5,7-trihydroxy-4Hchromen-4-one (3). A solution of $22 \mathrm{c}(61 \mathrm{mg}, 122 \mu \mathrm{mol})$ in dry THF (3 mL) was hydrogenated at $\mathrm{rt}$ in the presence of $20 \%$ palladium hydroxide on carbon $(10 \mathrm{mg})$. After stirring for approximately $3 \mathrm{~h}$ until TLC showed that the reaction was complete, the catalyst was filtered, and the solvent was evaporated to afford $23 \mathbf{c}$, which was subjected to the next step without purification. Dimethyl taxifolin $23 \mathrm{c}$ in ethanol $(1 \mathrm{~mL})$ was added to $20 \%$ potassium metabisulphite $(2 \mathrm{~mL})$, and then stirred at $100{ }^{\circ} \mathrm{C}$ for $5 \mathrm{~h}$. The reaction mixture wad taken into ice water, the precipitate was filtered to give $33.2 \mathrm{mg}$ (total yield from 22c: $86 \%$ ) of 3 as yellow solid; $\mathrm{mp}>290{ }^{\circ} \mathrm{C} ;{ }^{1} \mathrm{H}-\mathrm{NMR}\left(\mathrm{CD}_{3} \mathrm{OD}\right) \delta 2.25$ $(\mathrm{s}, 3 \mathrm{H}), 6.16(\mathrm{~d}, J=2.0 \mathrm{~Hz}, 1 \mathrm{H}), 6.37(\mathrm{~d}, J=2.0 \mathrm{~Hz}, 1 \mathrm{H}), 7.50(\mathrm{~d}, J$ $=1.5 \mathrm{~Hz}, 1 \mathrm{H}), 7.60(\mathrm{~d}, J=2.0 \mathrm{~Hz}, 1 \mathrm{H}) ;{ }^{13} \mathrm{C}-\mathrm{NMR}\left(\mathrm{CD}_{3} \mathrm{OD}\right) \delta 16.3$, 94.4, 99.2, 104.5, 113.5, 122.9, 123.1, 125.7, 137.1, 145.6, 147.1, 148.2, 158.2, 162.5, 165.5, 177.2; HR-MS $\left(\mathrm{FAB}^{+}\right)$calcd for $\mathrm{C}_{16} \mathrm{H}_{13} \mathrm{O}_{7}[\mathrm{M}+\mathrm{H}]^{+}:$317.0694, found 317.0661.

1-(2,4-Bis(benzyloxy)-6-hydroxyphenyl)ethan-1-one (10a). The benzylation compound $\mathbf{1 0}$ was prepared in analogy to a procedure by Yamasaki et al. ${ }^{48}$ Benzyl bromide $(11.80 \mathrm{~mL}$, $99.33 \mathrm{mmol}$ ) was added dropwise to a solution of 2,4,6-trihydroxyacetophenone monohydrate $(7.396 \mathrm{~g}, 39.73 \mathrm{mmol})$ and potassium carbonate $(13.96 \mathrm{~g}, 99.33 \mathrm{mmol})$ in dry DMF $(20 \mathrm{~mL})$, and mixture was stirred for overnight at $\mathrm{rt}$. The solution was diluted with $\mathrm{CH}_{2} \mathrm{Cl}_{2}$, washed with brain, and dried over $\mathrm{Na}_{2} \mathrm{SO}_{4}$. After removal of the solvent under reduced pressure, the residue was purified by column chromatography on silica gel $(20: 1$ to $10: 1 n$-hexane-ethyl acetate) to give $4.516 \mathrm{~g}$ (33\%) of $10 \mathrm{a}$ as white solid; mp $110-111{ }^{\circ} \mathrm{C} ;{ }^{1} \mathrm{H}-\mathrm{NMR}\left(\mathrm{CDCl}_{3}\right) \delta 2.54(\mathrm{~s}, 3 \mathrm{H}), 5.04$ $(\mathrm{s}, 2 \mathrm{H}), 5.05(\mathrm{~s}, 2 \mathrm{H}), 6.09$ (d, $J=2.4 \mathrm{~Hz}, 1 \mathrm{H}), 6.15(\mathrm{~d}, J=2.4 \mathrm{~Hz}$, $1 \mathrm{H}), 7.31-7.40(\mathrm{~m}, 10 \mathrm{H}), 14.02(\mathrm{~s} 1 \mathrm{H}) ;{ }^{13} \mathrm{C}-\mathrm{NMR}\left(\mathrm{CD}_{3} \mathrm{Cl}\right) \delta 32.9$, 69.9, 70.7, 92.0, 94.4, 106.0, 127.3, 127.6, 128.0, 128.1, 128.3, 128.4, 135.2 , 135.5, 161.6, 164.7, 167.2, 202.8; HR-MS (ESI) calcd for $\mathrm{C}_{22} \mathrm{H}_{21} \mathrm{O}_{4}[\mathrm{M}+\mathrm{H}]^{+}:$349.1440, found 349.1440.

(E)-3-(3,4-Bis(benzyloxy)-2,5-dimethylphenyl)-1-(2,4-bis (benzyloxy)-6-hydroxyphenyl)prop-2-en-1-one (14). To a mixture of 9a $(1.68 \mathrm{~g}, 4.74 \mathrm{mmol})$ and $10 \mathrm{a}(1.64 \mathrm{~g}, 4.74 \mathrm{mmol})$ in dry dioxane $(8.0 \mathrm{~mL})$ at $\mathrm{rt}$ under $\mathrm{Ar}$, ethanol $(13.5 \mathrm{~mL})$ and $40 \%$ 
aqueous potassium hydroxide $(3.9 \mathrm{~mL})$ were added. The resulting solution was stirred at $\mathrm{rt}$ for overnight, the solution was diluted with ethyl acetate, washed with $1 \mathrm{~N} \mathrm{HCl}$ and brain. The organic phase was dried over $\mathrm{Na}_{2} \mathrm{SO}_{4}$, filtered and the solvent was evaporated. The residue was purified by column chromatography on silica gel ( $3: 1$ to $2: 1 n$-hexane- $\mathrm{CH}_{2} \mathrm{Cl}_{2}$ ) to give $2.70 \mathrm{~g}(84 \%)$ of 14 as yellow liquid; ${ }^{1} \mathrm{H}-\mathrm{NMR}\left(\mathrm{CDCl}_{3}\right) \delta 1.98$ $(\mathrm{s}, 3 \mathrm{H}), 2.31(\mathrm{~s}, 3 \mathrm{H}), 4.96(\mathrm{~s}, 2 \mathrm{H}), 5.04(\mathrm{~s}, 2 \mathrm{H}), 5.09(\mathrm{~s}, 2 \mathrm{H}), 5.10(\mathrm{~s}$, $2 \mathrm{H}), 6.17(\mathrm{~d}, J=2.5 \mathrm{~Hz}, 1 \mathrm{H}), 6.23(\mathrm{~d}, J=2.5 \mathrm{~Hz}, 1 \mathrm{H}), 6.79(\mathrm{~s}, 1 \mathrm{H})$, 7.26-7.43 (m, 20H), 7.77 (d, $J=15.5 \mathrm{~Hz}, 1 \mathrm{H}), 8.03$ (d, $J=15.5 \mathrm{~Hz}$, $1 \mathrm{H}) ;{ }^{13} \mathrm{C}-\mathrm{NMR}\left(\mathrm{CD}_{3} \mathrm{Cl}\right) \delta 12.1,16.2,70.3,71.3,74.8,74.9,92.8$, 95.0, 106.7, 124.4, 127.5, 127.6, 127.7, 127.7, 128.0, 128.1, 128.4, $128.5,128.5,128.6,128.7,129.9$, 130.4, 131.2, 135.6, 135.9, 137.3, 137.5, 140.2 , 150.2, 152.0, 161.6, 165.1, 168.4, 192.8; HRMS (ESI) calcd for $\mathrm{C}_{45} \mathrm{H}_{40} \mathrm{O}_{6}[\mathrm{M}+\mathrm{Na}]^{+}:$699.2717, found 699.2686 .

(Z)-4,6-Bis(benzyloxy)-2-(3,4-bis(benzyloxy)-2,5-dimethyl benzylidene)benzofuran-3(2H)-one (16). Ethanol $(100 \mathrm{~mL})$ and $5.4 \%$ aqueous sodium hydroxide $(35 \mathrm{~mL})$ were added to a solution of $14(1.88 \mathrm{~g}, 2.78 \mathrm{mmol})$ in 1,4-dioxiane (40 mL), and then added $30 \%$ hydrogen peroxide solution $(3.8 \mathrm{~mL})$ at $0{ }^{\circ} \mathrm{C}$. The resulting mixture was stirred at $\mathrm{rt}$ for overnight, the solution was diluted with $\mathrm{CH}_{2} \mathrm{Cl}_{2}$, washed with $1 \mathrm{~N} \mathrm{HCl}$. The organic phase was dried over $\mathrm{Na}_{2} \mathrm{SO}_{4}$, filtered and the solvent was evaporated. The residue was purified by column chromatography on silica gel (6:4:1 $n$-hexane- $\left.\mathrm{CH}_{2} \mathrm{Cl}_{2}-\mathrm{MeOH}\right)$ to give $1.02 \mathrm{~g}(53.2 \%)$ of 16 as a yellow solid; mp $152-155{ }^{\circ} \mathrm{C} ;{ }^{1} \mathrm{H}-\mathrm{NMR}$ $\left(\mathrm{CDCl}_{3}\right) \delta 2.29(\mathrm{~s}, 3 \mathrm{H}), 2.36(\mathrm{~s}, 3 \mathrm{H}), 4.98(\mathrm{~s}, 2 \mathrm{H}), 5.06(\mathrm{~s}, 2 \mathrm{H}), 5.11$ $(\mathrm{s}, 2 \mathrm{H}), 5.28(\mathrm{~s}, 2 \mathrm{H}), 6.25(\mathrm{~d}, J=2.0 \mathrm{~Hz}, 1 \mathrm{H}), 6.47(\mathrm{~d}, J=2.0 \mathrm{~Hz}$, $1 \mathrm{H}), 6.94(\mathrm{~s}, 1 \mathrm{H}), 7.33-7.49(\mathrm{~m}, 20 \mathrm{H}), 7.79(\mathrm{~s}, 1 \mathrm{H}) ;{ }^{13} \mathrm{C}-\mathrm{NMR}$ $\left(\mathrm{CD}_{3} \mathrm{Cl}\right) \delta 12.5,16.4,70.6,70.8,74.8,75.0,90.6,96.4,106.0$, $107.9,126.7,127.4,127.6,127.9$, 128.1, 128.1, 128.4, 128.5, $128.5,128.6,128.8,130.1,131.8,135.5,136.0,137.3,137.5$, 147.6, 150.4 151.6, 158.4, 167.6, 168.9, 180.5; HR-MS (ESI) calcd for $\mathrm{C}_{45} \mathrm{H}_{38} \mathrm{O}_{6}[\mathrm{M}+\mathrm{Na}]^{+}:$697.2561, found 697.2526.

2-(3,4-Dihydroxy-2,5-dimethylbenzyl)-4,6-dihydroxybenzofuran3(2H)-one (17). A solution of $16(260.1 \mathrm{mg}, 396 \mu \mathrm{mol})$ in dry THF $(16 \mathrm{~mL})$ was hydrogenated at $\mathrm{rt}$ in the presence of $20 \%$ palladium hydroxide on carbon (120 mg). After stirring for approximately $2 \mathrm{~h}$, the catalyst was filtered, and the solvent was evaporated to afford 17 as gray solid; $233-236{ }^{\circ} \mathrm{C} ;{ }^{1} \mathrm{H}-\mathrm{NMR}\left(\mathrm{CD}_{3} \mathrm{OD}\right) \delta 2.13(\mathrm{~s}, 3 \mathrm{H}), 2.16$ $(\mathrm{s}, 3 \mathrm{H}), 2.76(\mathrm{dd}, J=9.0,15.0 \mathrm{~Hz}, 1 \mathrm{H}), 3.17(\mathrm{dd}, J=4.0,15.5 \mathrm{~Hz}$, $1 \mathrm{H}), 4.66(\mathrm{dd}, J=4.0,9.0 \mathrm{~Hz}, 1 \mathrm{H}), 5.84(\mathrm{~d}, J=1.5 \mathrm{~Hz}, 1 \mathrm{H}), 5.88(\mathrm{~d}, J$ $=1.5 \mathrm{~Hz}, 1 \mathrm{H}), 6.52(\mathrm{~s}, 1 \mathrm{H}) ;{ }^{13} \mathrm{C}-\mathrm{NMR}\left(\mathrm{CD}_{3} \mathrm{OD}\right) \delta 12.7,16.5,36.2$, 88.8, 91.8, 97.6, 104.4, 123.2, 123.4, 124.8, 128.1, 143.6, 145.0, 159.9, 171.0, 176.8, 199.7; HR-MS (ESI) calcd for $\mathrm{C}_{17} \mathrm{H}_{17} \mathrm{O}_{6}[\mathrm{M}+$ $\mathrm{H}]^{+}$: 317.1025, found 317.1012.

5,7-Bis(benzyloxy)-2-(3,4-bis(benzyloxy)-2,5-dimethylphenyl)4H-chromen-4-one (18). To a mixture of 14 (138.1 mg, 198.9 $\mu \mathrm{mol})$ and iodine $(13.0 \mathrm{mg}, 51.2 \mu \mathrm{mol})$ in DMSO $(2.7 \mathrm{~mL})$ was heated at $110{ }^{\circ} \mathrm{C}$ for overnight. The solution was diluted with ethyl acetate, washed with $1 \mathrm{~N} \mathrm{HCl}$ and brain, and dried over $\mathrm{Na}_{2} \mathrm{SO}_{4}$, filtered and the solvent was evaporated. The residue was purified by column chromatography on silica gel ( $3: 1$ to $2: 1 n$-hexane-ethyl acetate) to give $131.2 \mathrm{mg}$ (82\%) of 18 as brown solid; mp 55-57 ${ }^{\circ} \mathrm{C} ;{ }^{1} \mathrm{H}-\mathrm{NMR}\left(\mathrm{CDCl}_{3}\right) \delta 2.28(\mathrm{~s}, 3 \mathrm{H}), 2.31$ $(\mathrm{s}, 3 \mathrm{H}), 5.04(\mathrm{~s}, 2 \mathrm{H}), 5.07$ (s, 2H), $5.09(\mathrm{~s}, 2 \mathrm{H}), 5.24(\mathrm{~s}, 2 \mathrm{H}), 6.28$ (s,
$1 \mathrm{H}), 6.52(\mathrm{~d}, J=2.5 \mathrm{~Hz}, 1 \mathrm{H}), 6.57(\mathrm{~d}, J=2.5 \mathrm{~Hz}, 1 \mathrm{H}), 7.13(\mathrm{~s}, 1 \mathrm{H})$, 7.37-7.64 (m, 20H); ${ }^{13} \mathrm{C}-\mathrm{NMR}\left(\mathrm{CD}_{3} \mathrm{Cl}\right) \delta$ 13.6, 16.1, 70.5, 70.7, 74.9, 74.9, 94.2, 98.3, 109.7, 113.5, 126.6, 126.8, 127.6, 128.2, 128.4 , 128.4, 128.4, 128.5, 128.6, 128.8, 128.8, 129.6, 130.6, $135.6,136.4,137.2,137.3,150.8,152.3,159.8,160.0,162.7$, 162.9, 177.2; HR-MS (ESI) calcd for $\mathrm{C}_{45} \mathrm{H}_{38} \mathrm{O}_{6}[\mathrm{M}+\mathrm{H}]^{+}$: 675.2741, found 675.2710 .

\section{Antioxidant activity measurements}

Since phenoxyl radical generated in the reaction of quercetin analogues with oxyl radicals readily reacts with molecular oxygen, the reactions were carried out under strictly deaerated conditions. A continuous flow of argon gas was bubbled through an acetonitrile solution $(3.0 \mathrm{~mL})$ containing galvinoxyl radical $\left(\mathrm{GO}^{\circ}, 2.0 \times 10^{-6} \mathrm{M}\right)$ in a square quartz cuvette with a glass tube neck for $7 \mathrm{~min}$. Air was prevented from leaking into the neck of the cuvette with a rubber septum. Typically, an aliquot of quercetin analogues (quercetins were maintained at more than 10 -fold excess to the $\mathrm{GO}^{\circ}$ concentration), which were dissolved in deaerated acetonitrile, were added to the cuvette with a microsyringe to initiate the reaction of quercetin analogues with $\mathrm{GO}^{\circ}$. UV-vis spectral changes associated with the reaction were monitored using an Agilent 8453 photodiode array spectrometer. The rate of the GO scavenging reaction of quercetin analogues was determined by monitoring the absorbance change at $428 \mathrm{~nm}$ due to $\mathrm{GO}^{\circ}(\varepsilon$ $=1.32 \times 10^{5} \mathrm{M}^{-1} \mathrm{~cm}^{-1}$ ) using a stopped flow technique on a UNISOKU RSP-1000-02NM spectrophotometer. The pseudo first-order rate constants $\left(k_{\text {obs }}\right)$ were determined by leastsquares curve fit using an Apple MacBook Pro personal computer. The first-order plots of $\ln \left(A-A_{\infty}\right) v s$. time ( $A$ and $A_{\infty}$ denote the absorbance at the reaction time and the final absorbance, respectively) were linear until three or more halflives with a correlation coefficient $\rho>0.999$.

\section{Theoretical calculations}

Density functional theory (DFT) calculations were carried out on an 8CPU workstation (PQS, Quantum Cube QS8-2400C-064). The geometry optimisations were performed using the B3LYP/ 6-31G(d) basis set for the radical with the unrestricted Hartree-Fock (UHF) formalism as implemented in the Gaussian 09 program Revision A. 02 . The BDE values were determined by the single point energy calculations at the B3LYP/6-31G(d) basis set with the restricted open-shell Hartree-Fock (ROHF) formalism.

\section{Acknowledgements}

This work was partially supported by Grant-in-Aid (15K18901 to K. I. and 26460056 to I. N.) from the Ministry of Education, Culture, Sports, Science and Technology, Japan, and the Sasakawa Scientific Research Grant from the Japan Science Society (K. I.). We thank Ms Y. Odanaka and Ms S. Matsubayashi at the Center for Instrumental Analysis of Showa University for assistance with NMR and MS measurements. 


\section{Notes and references}

1 Y. Du, G. Wei and R. J. Linhardt, J. Org. Chem., 2004, 69, 2206-2209.

2 S. Renaud and L. M. de, Lancet, 1992, 339, 1523-1526.

3 A. Scalbert, C. Manach, C. Morand, C. Rémésy and L. Jiménez, Crit. Rev. Food Sci. Nutr., 2005, 45, 287-306.

4 H. Tanaka, M. M. Stohlmeyer, T. J. Wandless and L. P. Taylor, Tetrahedron Lett., 2000, 41, 9735-9739.

5 B. B. Aggarwal, C. Sundaram, S. Prasad and R. Kannappan, Biochem. Pharmacol., 2010, 80, 1613-1631.

6 S. L. Albarracin, B. Stab, Z. Casas, J. J. Sutachan, I. Samudio, J. Gonzalez, L. Gonzalo, F. Capani, L. Morales and G. E. Barreto, Nutr. Neurosci., 2012, 15, 1-9.

7 S. Arranz, G. Chiva-Blanch, P. Valderas-Martinez, A. MedinaRemon, R. M. Lamuela-Raventos and R. Estruch, Nutrients, 2012, 4, 759-781.

8 M. Gonzalez-Vallinas, M. Gonzalez-Castejon, A. RodriguezCasado and d. M. A. Ramirez, Nutr. Rev., 2013, 71, 585-599.

9 G. Aliev, M. E. Obrenovich, V. P. Reddy, J. C. Shenk, P. I. Moreira, A. Nunomura, X. Zhu, M. A. Smith and G. Perry, Mini-Rev. Med. Chem., 2008, 8, 1395-1406.

10 W. A. Pryor, Free Radical Biol. Med., 2000, 28, 141-164.

11 H. E. Seifried, D. E. Anderson, E. I. Fisher and J. A. Milner, J. Nutr. Biochem., 2007, 18, 567-579.

12 E. Anouar, C. A. Calliste, P. Kosinova, F. Di Meo, J. L. Duroux, Y. Champavier, K. Marakchi and P. Trouillas, J. Phys. Chem. A, 2009, 113, 13881-13891.

13 K. Inami, Y. Iizuka, M. Furukawa, I. Nakanishi, K. Ohkubo, K. Fukuhara, S. Fukuzumi and M. Mochizuki, Bioorg. Med. Chem., 2012, 20, 4049-4055.

14 S. Quideau, D. Deffieux, C. Douat-Casassus and L. Pouysegu, Angew. Chem., Int. Ed., 2011, 50, 586-621.

15 I. Nakanishi, T. Shimada, K. Ohkubo, S. Manda, T. Shimizu, S. Urano, H. Okuda, N. Miyata, T. Ozawa, K. Anzai, S. Fukuzumi, N. Ikota and K. Fukuhara, Chem. Lett., 2007, 36, 1276-1277.

16 S. Mitani, A. Ouchi, E. Watanabe, Y. Kanesaki, S.-I. Nagaoka and K. Mukai, J. Agric. Food Chem., 2008, 56, 4406-4417.

17 I. Nakanishi, K. Miyazaki, T. Shimada, K. Ohkubo, S. Urano, N. Ikota, T. Ozawa, S. Fukuzumi and K. Fukuhara, J. Phys. Chem. A, 2002, 106, 11123-11126.

18 O. Dangles, G. Fargeix and C. Dufour, J. Chem. Soc., Perkin Trans. 2, 1999, 1387-1395.

19 M. Leopoldini, T. Marino, N. Russo and M. Toscano, J. Phys. Chem. A, 2004, 108, 4916-4922.

20 I. Nakanishi, K. Fukuhara, T. Shimada, K. Ohkubo, Y. Iizuka, K. Inami, M. Mochizuki, S. Urano, S. Itoh, N. Miyata and S. Fukuzumi, J. Chem. Soc., Perkin Trans. 2, 2002, 1520-1524.

21 I. Nakanishi, T. Kawashima, K. Ohkubo, H. Kanazawa, K. Inami, M. Mochizuki, K. Fukuhara, H. Okuda, T. Ozawa, S. Itoh, S. Fukuzumi and N. Ikota, Org. Biomol. Chem., 2005, 3, 626-629.

22 N. S. Alrawaiq and A. Abdullah, Int. J. PharmTech Res., 2014, 6, 933-941.
23 W. M. Loke, J. M. Proudfoot, J. M. Hodgson, A. J. McKinley, N. Hime, M. Magat, R. Stocker and K. D. Croft, Arterioscler., Thromb., Vasc. Biol., 2010, 30, 749-757.

24 A. B. Bentz, Journal of Young Investigators, 2009, 19, 1-14.

25 N. A. Kelsey, H. M. Wilkins and D. A. Linseman, Molecules, 2010, 15, 7792-7814.

26 A. Mattarei, N. Sassi, C. Durante, L. Biasutto, G. Sandonà, E. Marotta, S. Garbisa, A. Gennaro, C. Paradisi and M. Zoratti, Eur. J. Org. Chem., 2011, 2011, 5577-5586.

27 M. Salas-Reyes, J. Hernández, z. Domínguez, F. J. González, P. D. Astudillo, R. E. Navarro, E. Martínez-Benavidez, C. Velázquez-Contreras and S. Cruz-Sánchez, J. Braz. Chem. Soc., 2011, 22, 693-701.

28 K. Fukuhara, I. Nakanishi, A. Matsuoka, T. Matsumura, S. Honda, M. Hayashi, T. Ozawa, N. Miyata, S. Saito, N. Ikota and H. Okuda, Chem. Res. Toxicol., 2008, 21, 282287.

29 K. Imai, I. Nakanishi, A. Ohno, M. Kurihara, N. Miyata, K. Matsumoto, A. Nakamura and K. Fukuhara, Bioorg. Med. Chem. Lett., 2014, 24, 2582-2584.

30 K. Fukuhara, I. Nakanishi, H. Kansui, E. Sugiyama, M. Kimura, T. Shimada, S. Urano, K. Yamaguchi and N. Miyata, J. Am. Chem. Soc., 2002, 124, 5952-5953.

31 K. Imai, I. Nakanishi, K. Anzai, T. Ozawa, N. Miyata, S. Urano, H. Okuda, A. Nakamura and K. Fukuhara, Chem. Lett., 2011, 40, 1417-1419.

32 T. Oyamada, Bull. Chem. Soc. Jpn., 1935, 10, 182-186.

33 T. Oyamada, J. Chem. Soc. Jpn., 1934, 55, 1256-1261.

34 J. Algar and J. P. Flynn, Proc. R. Ir. Acad., Sect. B, 1934, 42, 1-8.

35 M. Iwatsu, D. Urabe and M. Inoue, Heterocycles, 2010, 82, 491-504.

36 M. Bennett, A. J. Burke and W. I. O'Sullivan, Tetrahedron, 1996, 52, 7163-7178.

37 Z. Wu, S. Cai, W. Fan and Q. Wang, Chin. J. Org. Chem., 2012, 32, 1296.

38 W.-J. Jiang, K. I. Ishiuchi, M. Furukawa, T. Takamiya, S. Kitanaka and H. Iijima, Bioorg. Med. Chem., 2015, 23, 6922-6929.

39 N. Pandurangan, C. Bose and A. Banerji, Bioorg. Med. Chem. Lett., 2011, 21, 5328-5330.

40 L. X. Yang, K. X. Huang, H. B. Li, J. X. Gong, F. Wang, Y. B. Feng, Q. F. Tao, Y. H. Wu, X. K. Li, X. M. Wu, S. Zeng, S. Spencer, Y. Zhao and J. Qu, J. Med. Chem., 2009, 52, 7732-7752.

41 M. Sato, K. Murakami, M. Uno, Y. Nakagawa, S. Katayama, K.-i. Akagi, Y. Masuda, K. Takegoshi and K. Irie, J. Biol. Chem., 2013, 288, 23212-23224.

42 A. Masa, M. Vilanova and F. Pomar, J. Chromatogr. A, 2007, 1164, 291-297.

43 C. R. Razafindrabe, S. Aubry, B. Bourdon, M. Andriantsiferana, S. Pellet-Rostaing and M. Lemaire, Tetrahedron, 2010, 66, 9061-9066.

44 R. Tanifuji, H. Oguri, K. Koketsu, Y. Yoshinaga, A. Minami and H. Oikawa, Tetrahedron Lett., 2016, 57, 623-626. 
45 B. A. Cevallos-Casals and L. Cisneros-Zevallos, J. Agric. Food Chem., 2003, 51, 3313-3319.

46 A. K. Sinhababu, A. K. Ghosh and R. T. Borchardt, J. Med. Chem., 1985, 28, 1273-1279.
47 M. Ghosh, G. K. Kar, J. K. Ray and B. G. Chatterjee, Synth. Commun., 1983, 13, 667-675.

48 K. Yamasaki, R. Hishiki, E. Kato and J. Kawabata, ACS Med. Chem. Lett., 2011, 2, 17-21. 